\title{
Antigen-Based Immune Therapeutics for Type 1 Diabetes: Magic Bullets or Ordinary Blanks?
}

\author{
Slobodan Culina,, ${ }^{1,2}$ Christian Boitard, 1, 2,3 and Roberto Mallone, 2,3 \\ ${ }^{1}$ INSERM, U986, DeAR Lab Avenir, Saint Vincent de Paul Hospital, 82 avenue Denfert Rochereau, 75674 Paris Cedex 14, France \\ ${ }^{2}$ Université Paris-Descartes, 75006 Paris, France \\ ${ }^{3}$ Assistance Publique Hôpitaux de Paris, Hôtel Dieu, Service de Diabétologie, 75181 Paris, France
}

Correspondence should be addressed to Roberto Mallone, roberto.mallone@inserm.fr

Received 16 January 2011; Revised 7 March 2011; Accepted 8 March 2011

Academic Editor: Aziz Alami Chentoufi

Copyright (C) 2011 Slobodan Culina et al. This is an open access article distributed under the Creative Commons Attribution License, which permits unrestricted use, distribution, and reproduction in any medium, provided the original work is properly cited.

The ideal drug of modern medicine is the one that achieves its therapeutic target with minimal adverse effects. Immune therapy of Type 1 diabetes (T1D) is no exception, and knowledge of the antigens targeted by pathogenic T cells offers a unique opportunity towards this goal. Different antigen formulations are being considered, such as proteins or peptides, either in their native form or modified ad hoc, DNA plasmids, and cell-based agents. Translation from mouse to human should take into account important differences, particularly in the time scale of autoimmune progression, and intervention. Critical parameters such as administration route, dosing and interval remain largely empirical and need to be further dissected. T1D staging through immune surrogate markers before and after treatment will be key in understanding therapeutic actions and to finally turn ordinary blanks into magic bullets.

\section{Introduction}

Type 1 diabetes (T1D), one of the most common autoimmune diseases, stems from defects in central and peripheral tolerance that lead to progressive T-cell-mediated destruction of insulin-producing $\beta$ cells in pancreatic islets. Clinically, this destruction results in the inability of affected individuals to produce the insulin required to properly regulate glucose metabolism, causing substantial morbidity and mortality. Although metabolic derangements are only the consequences of the underlying autoimmune pathogenesis, they remain the only targets of mainstream insulin therapy. Immune-targeted interventions which could correct autoimmune mechanisms are, therefore, intensively sought as a more rational approach. Preclinical studies largely take advantage of the nonobese diabetic (NOD) mouse, which is one rare instance of autoimmune model, where disease develops spontaneously rather than being induced by experimental manipulation.

\section{Translating the NOD Mouse into Human}

There is a long list of immune biologics that have spectacular effects in preventing T1D in the NOD mouse. However, only a handful of them has shown some effect once translated into clinical trials. There are a number of reasons explaining these discrepancies which should be kept in mind. First is the phylogenetic difference between the murine and human immune system, which is not surprising considering that the two species diverged $\sim 70$ million years ago [1]. Second, although the NOD is a spontaneous model of T1D which is linked to MHC susceptibility haplotypes and involves a complex immune interplay like in human, there are important discrepancies. These include characteristics of the insulitis infiltrate, autoantibody ( $\mathrm{aAb}$ ) specificities, and association with other autoimmune manifestations (e.g., sialitis). Third, the NOD is an inbred strain composed of genetically identical animals. As such, it can be assimilated to one single T1D patient, and indeed a very peculiar one. 
Further underrepresenting human disease, these mice are kept under identical environmental conditions, protected from most infectious threats. Fourth, disease and treatment kinetics are quite different, as NOD mice are most commonly treated for preventing diabetes at an early stage, before the appearance of any circulating autoimmune marker such as anti-insulin aAbs (IAA). This is rarely possible in humans, as further discussed. Indeed, when we look at immune therapies which work in the NOD mouse once the disease has become clinically overt, the list of effective treatments falls much shorter. The challenge that intervention trials face in humans is thus a formidable one. For this reason, we will focus our discussion on antigen- (Ag-) specific agents that have already been tested or are soon to enter clinical trials, reasoning that our goal is to cure men rather than mice.

\section{Immune Therapy for Type 1 Diabetes: Whom for?}

Studies in the NOD mouse suggest that the great majority of the $\beta$-cell mass $(\sim 75 \%)$ has already been destroyed by the time of diabetes onset [2]. A recent meta-analysis and mathematical modeling of three landmark histopathological studies of human T1D pancreata [3-5] suggests that this is also the case in humans [6]. However, the extent of $\beta$-cell destruction varies with age, ranging from $85 \%$ in children to $40 \%$ in adults [6]. This is probably due to a combination of factors, which include a physiological age-related decline in $\beta$-cell mass, differences in insulin needs according to body weight, growth and insulin sensitivity, and the degree of $\beta$-cell autoimmunity, which may be more aggressive in younger patients. One limitation of most histopathological studies is that measurement of residual $\beta$-cell mass was based on enumeration of insulin-positive cells within the islets. It is, thus, possible that viable $\beta$ cells not producing insulin because of functional impairment are missed, leading to an overestimation. It is also difficult to relate these histopathological estimates of residual $\beta$-cell mass with those of residual $\beta$-cell function, as determined by stimulated C-peptide secretion. However, recent studies suggest that insulin production may be more substantial at diagnosis than had been previously appreciated and that residual insulin secretion may persist in a subgroup of T1D patients [7]. Further complicating the picture, the question of whether significant $\beta$-cell renewal occurs in T1D patients remains unsettled [8].

Whichever the real extent of $\beta$-cell destruction at the time of T1D onset, it is clear that interventions aimed at correcting immune mechanisms should be implemented as early as possible, ideally at a preclinical stage in as yet healthy subjects at risk of developing disease (Figure 1). A related problem is, therefore, to reliably identify these subjects. Although genetic markers (particularly HLA Class II susceptibility alleles) and serum aAbs against the $\beta$-cell Ags insulin, glutamic acid decarboxylase (GAD), insulinoma-associated protein 2 (IA2 ), and zinc transporter 8 (ZnT8) greatly help to stratify T1D risk, they fall short in accuracy, as they can predict the risk but not the time course of disease development (i.e., the "if", but not the "when"), and much less when only one $\mathrm{aAb}$ marker is present. The accuracy of these predictions needs to be very stringent if used to decide enrollment into a clinical trial, because the risk-benefit balance is a delicate one for T1D. We are not facing a rapidly lethal disease but rather one that, despite difficult daily management and longterm complications, carries a life expectancy which is getting closer and closer to normal. This benign prognosis needs to be weighed against the risks of experimental immune therapeutics, whose long-term adverse events are frequently unknown. It is, therefore, ethically acceptable to trial only those subjects in whom T1D will eventually develop. Given the efforts and difficulties needed to recruit an adequate number of at-risk subjects, T1D prevention studies have been quite limited and performed mostly in subjects at very high risk. Trials in newly diagnosed T1D patients are more common, with the inner constraint that, even if the autoimmune process is effectively halted, there is limited clinical benefit to be expected from rescuing the residual $\beta$ cell mass. This is particularly daunting in T1D children, in whom the remaining $\beta$ cells are fewer than in adults and may be as few as $15 \%$ [6]. In this respect, combination of immune biologics with strategies aimed at replacing or regenerating lost $\beta$ cells may expand the optimal time window for intervention.

\section{Immune Suppression versus Tolerance Restoration}

Two broad strategies could theoretically be followed to intervene on $\beta$-cell autoimmunity. The first one would consist of correcting the environmental causes triggering autoimmunity. However, this is certainly the most frustrating failure of half a century of T1D research, which has elucidated a wealth of immune mechanisms without identifying the environmental primi moventes. The only emerging exception may be the role of the gut microbiome, as data obtained in the NOD mouse suggests that altering composition of intestinal flora may offer new treatment paths in the future [9]. Factors responsible for insulin resistance are also emerging contributors to T1D development, but they probably play a precipitating rather than causative role. Nonetheless, insulin resistance has recently been recognized as a powerful T1D risk factor [10], and clinical trials with drugs such as metformin acting on metabolic pathways keep being investigated [11-13].

The second, currently more viable, strategy is to correct immune mechanisms. In doing this, an important difference needs to be made between immune suppression and tolerance restoration. With immune suppression, a generalized status of lessened reactivity is induced so that the body has decreased responses to Ag challenges of any kind. This exposes to increased risks of infection and secondary tumor growth. Moreover, treatment needs to be lifelong, as its effects are lost after discontinuation. Immune suppression is typically induced by drugs that act on common signaling pathways used by key immune cells. Examples of such drugs used in the past are cyclosporin A [14] and, in more 


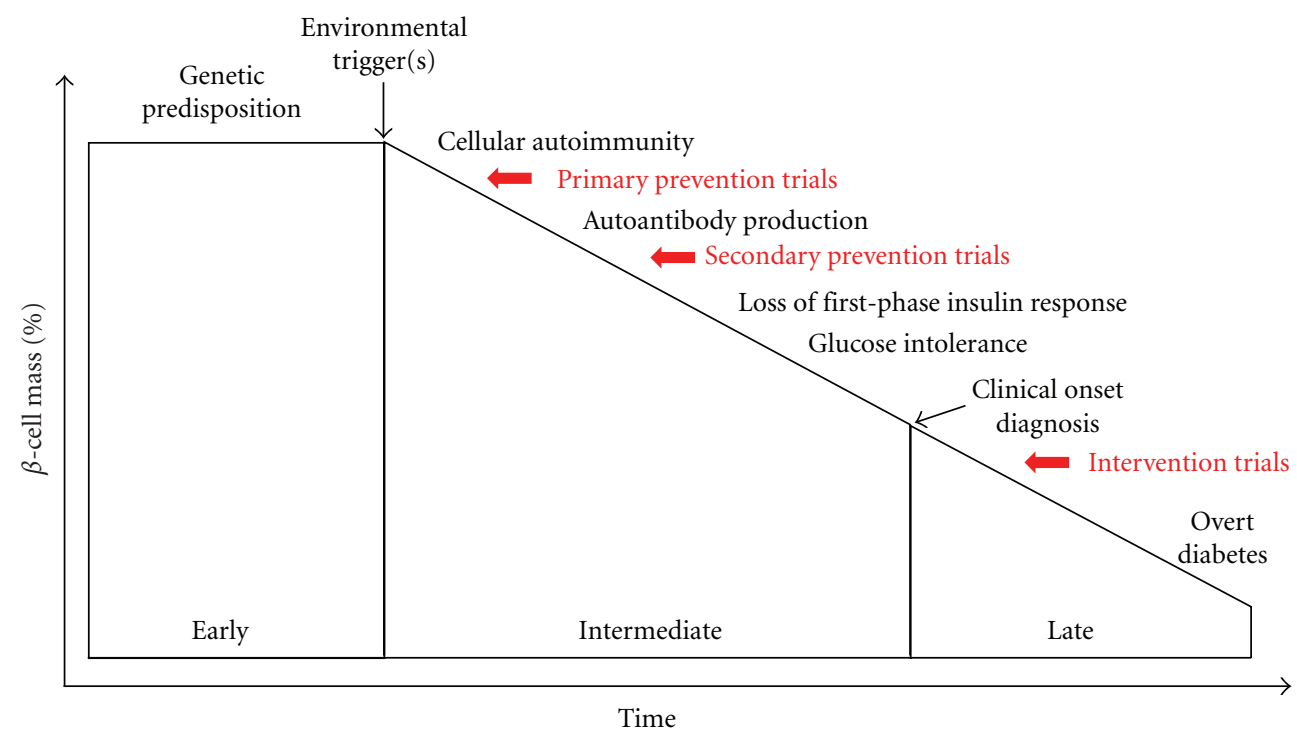

FIgURE 1: Stages of disease progression and intervention in T1D. Progression over time ( $X$-axis) from simple genetic susceptibility to $\beta$-cell autoimmunity and T1D is plotted against residual $\beta$-cell mass ( $Y$-axis). The time points at which immune therapies are administered are shown in red.

recent years, anti-CD25 monoclonal antibodies (mAbs) and mycofenolate mofetil, used either alone or in combination [15].

With immune tolerance restoration, the induced effect is not generalized but limited to specific types of responses, ideally only to responses specific to $\beta$-cell Ags. Thus, the immune system remains capable of responding to infectious and tumoral threats. Treatment should be limited in time, while the effects should persist after discontinuation. This is because an "active" effect is induced by boosting natural immune tolerance mechanisms. With this frame of reference, it is evident why immune restoration strategies are preferable. Given their more selective action and limited duration of treatment, their risk-benefit balance is more attractive, especially if they have to be applied in prevention trials. Although several non-Ag-specific therapeutic mAbs are also under scrutiny [16], agents that exploit the target $\beta$-cell Ags themselves may offer the best warranties of Ag-specific immune tolerance.

\section{Which $\beta$-Cell Antigens?}

The list of $\beta$-cell Ags relevant to T1D autoimmunity is quite long [17], but few of them have resisted the proof of time and proved to be key targets of $\mathrm{aAb}$ and/or T-cell responses. These Ags are insulin and its precursors proinsulin (PI) and preproinsulin (PPI), GAD, IA-2, ZnT8, and islet glucose-6phosphatase catalytic subunit-related protein (IGRP). The latter is the only one to be exclusively described as a target of T cells $[18,19]$, as aAbs have been sought after but not yet found.

A popular tenet in autoimmunity is that there could be one primary self Ag which initiates pathogenesis. Tissue destruction through targeting of this Ag could further release other ones, thus amplifying the autoimmune cascade through a phenomenon known as epitope spreading. In the NOD mouse, insulin has been identified as the initiating $\beta$-cell Ag. The importance of insulin is supported by data on insulin knockout NOD mice. Different from humans, rodents express two isoforms, referred to as insulin 1 and 2. NOD mice defective for the insulin 2 gene, the prevalent isoform in the thymus, display accelerated T1D [20], likely related to defective deletion of insulin-reactive T cells [21]. Conversely, NOD mice defective for the insulin 1 gene, one of the two isoforms expressed in the islets, are less susceptible to T1D [22]. However, insulin 1 knockout islets transplanted into recently diabetic wild-type NOD mice become infiltrated and only transiently reverse T1D, suggesting that insulin is an early but not exclusive target [22]. More recent evidence from Nakayama et al. further suggests that insulin may be the initiating $\beta$-cell Ag in T1D [23]. These authors produced NOD mice, where the endogenous insulin 1 and 2 genes have been deleted and replaced by a hormonally active insulin transgene carrying a single amino acid mutation at position B16. These mice are completely protected from T1D and insulitis [23]. Intriguingly, the introduced substitution affects insulin recognition by both CD4+ and CD8+ T cells, as two overlapping immunodominant epitopes have been described in this region: insulin $\mathrm{B}_{9-23}$ [24] and insulin $\mathrm{B}_{15-23}$ [25], respectively. These data suggest that recognition of these immunodominant epitopes by CD4+ and/or CD8+ T cells may be a mandatory early event in T1D pathogenesis. Studies by Krishnamurthy et al. further corroborated the hypothesis that insulin is the initiating Ag in the T1D of the NOD mouse, because mice rendered tolerant to insulin by transgenic overexpression of insulin 2 in Ag-presenting cells do not develop the immunodominant IGRP $206-214$-specific responses and are protected from T1D [26]. Conversely, mice made tolerant to IGRP by the same means are not protected 
from T1D [26], suggesting that IGRP-specific responses lay downstream of insulin-specific ones in the pathogenic cascade. The prerequisite of insulin-specific responses for T1D to develop is even found in NOD8.3 mice, which are transgenic for a T-cell receptor recognizing the $\mathrm{IGRP}_{206-214}$ epitope [27].

Despite strong evidence pointing to insulin's triggering role, identifying and targeting more $\beta$-cell Ags remain a highpriority goal. Several considerations justify these efforts. First, the evidence supporting insulin's critical role has been obtained in the NOD model, but similar evidence in human T1D is confined to the early appearance of IAA. Second, once autoimmune T-cell (and B-cell) responses to $\beta$ cells are initiated, the specificity of these responses rapidly enlarges to include more Ags (epitope spreading). As a result, responses to the presumable triggering $\mathrm{Ag}$ can be rapidly overgrown by secondary responses, as exemplified by IGRPspecific CD8+ T cells, which rapidly outnumber insulinspecific cells in the NOD model [28]. This consideration is particularly relevant in human, as even prevention trials enroll at-risk subjects at a relatively late stage, once the first signs of $\beta$-cell autoimmunity (i.e., aAbs) are already detectable, and Ag targeting has probably already diversified. Third, even among inbred NOD mice kept under identical environmental exposure, variations exist in the specificity of CD8+ T-cell responses [29]. Such variations are certainly more extensive in the outbred human population. Fourth, drawing a straight correlation between NOD mice and humans is a gross approximation even in the case of target Ags. Indeed, data in the NOD mouse suggest that GAD and IA-2 are dispensable Ags [30, 31], while they are major targets of aAbs and T-cell responses in humans, and even promising therapeutics in the case of GAD [32]. Of the $\beta$-cell Ags described, only insulin and GAD have reached the stage of clinical trials and will be discussed, as summarized in Table 1 .

Ag-based biologics can be divided into the following categories (Figure 2):

(i) whole proteins,

(ii) peptides,

(iii) modified protein and peptide Ags,

(iv) DNA plasmids,

(v) Ag-specific cell therapies.

\section{Whole Proteins}

The main advantage of using whole proteins is that they cover the complete amino acid sequence potentially available for epitope processing and presentation by Ag-presenting cells. Contrary to peptide epitopes, one single agent can be used in all patients, independently of their HLA haplotypes. However, production of the protein in recombinant form at sufficient purity and clinical grade can be challenging, as these preparations are frequently spiked with small contaminants carried over from the host bacteria, yeasts, or baculoviral systems that need to be removed. Only insulin and GAD have so far been employed as whole protein agents for T1D.
6.1. Insulin. The rationale of insulin-based T1D clinical trials is twofold. First, to restore insulin-specific immune tolerance. Second, to put the $\beta$ cell "at rest", by providing hormonally active exogenous insulin, thus avoiding to overload the endogenous secretory capacity. Indeed, metabolic stress could not only precipitate $\beta$-cell apoptosis [33], but also make $\beta$ cells more immunogenic and thus susceptible to destruction by autoreactive T cells [34].

Despite this appealing rationale and solid (pre)clinical grounds obtained in the NOD mouse [35-37] and in smallscale pilot human studies [38-40], a number of insulinbased trials, both preventative and interventional, have been disappointingly unsuccessful. Insulin of human origin was used in all of these studies. In the diabetes prevention trial-1 (DPT-1) [41], subjects at high risk of developing T1D were enrolled. These were defined as being positive for islet cell aAbs and already displaying early alterations of insulin secretion, documented by loss of the first-phase insulin response. For such subjects, the projected 5-year risk is $>50 \%$. Participants were treated with parenteral insulinsubcutaneous injections twice daily, plus annual intravenous infusions-for a median followup of 3.7 years. Subcutaneous ultralente insulin was administered at a dose of $0.125 \mathrm{U} / \mathrm{kg}$ twice daily and intravenous regular insulin given every 12 months for 4 days at a basal rate of $0.015 \mathrm{U} / \mathrm{kg} / \mathrm{h}$, which was increased for meals. Despite this intensive treatment, there was no protection on subsequent T1D development. Similar results were obtained in a smaller European trial employing subcutaneous insulin [42]. This outcome is not as surprising when comparing the DPT-1 strategy with its founding preclinical studies in the NOD mice [35]. Indeed, NOD mice were treated at doses of $0.5 \mathrm{U}$ per animal, that is, $\sim 25 \mathrm{U} / \mathrm{kg}$, a dose which is 200 -fold higher of what was used in the DPT-1. Regimens like those used in mouse studies would correspond to $1,750 \mathrm{U}$ for an average adult human, which is far above the maximal tolerable dose. Moreover, in most studies, NOD mice were treated continuously for up to 6 months. It is, thus, possible that insulin treated ongoing diabetes rather than preventing incipient disease in some animals. The risk of hypoglycemia is a major concern for translation into human, while mice are quite resistant to insulin-induced hypoglycemia, possibly due to stronger counter-regulatory hormone responses. Longeracting insulins such as glargine are now available which display a lower risk of hypoglycemia and constant levels throughout most of the day. This pharmacokinetic profile could be interesting not only in widening the therapeutic window of safe dosage, but also by providing low level Ag persistence without significant pulsatility, which may be more effective for tolerance induction [43]. Surprisingly, a mutated insulin (B25Asp) devoid of hypoglycemic activity (due to very low binding affinity for the insulin receptor) and preserving immunogenicity [44] has never been considered for clinical trials, despite encouraging studies in the NOD mouse [45]. B25Asp insulin could be administered at much higher doses, similar to those used in mice, while minimizing the risk of hypoglycemia.

The DPT- 1 trial also comprised an oral arm, in which atrisk subjects were treated by oral insulin $(7.5 \mathrm{mg} /$ day $)$ for a 
TABLE 1: Clinical trials in T1D using antigen-specific strategies.

\begin{tabular}{|c|c|c|c|c|c|c|c|}
\hline $\begin{array}{l}\text { Antigen } \\
\text { type }\end{array}$ & Antigen & Formulation & Route & Trial (Phase) & Subjects & $\begin{array}{c}\text { Outcome and/or } \\
\text { immune biomarkers }\end{array}$ & Reference \\
\hline Protein & Insulin & Short-acting insulin & Intravenous & $\begin{array}{l}\text { Intravenous insulin } \\
\text { (Phase I) }\end{array}$ & $\begin{array}{l}\text { Recent-onset } \\
\text { T1D }\end{array}$ & $\begin{array}{l}\text { Higher stimulated C } \\
\text { peptide and lower } \\
\text { HbAlc versus s.c. NPH } \\
\text { insulin }\end{array}$ & {$[38]$} \\
\hline Protein & Insulin & $\begin{array}{l}\text { (Ultra)lente/regular } \\
\text { insulin } \\
\text { (s.c.) }+ \text { short-acting } \\
\text { insulin (i.v.) }\end{array}$ & $\begin{array}{l}\text { Subcutaneous } \\
+ \text { Intravenous }\end{array}$ & $\begin{array}{l}\text { Joslin Insulin } \\
\text { Prophylaxis Trial } \\
\text { (Phase I) }\end{array}$ & At risk & Suggestive of efficacy & {$[39]$} \\
\hline Protein & Insulin & $\begin{array}{l}\text { Lente/short-acting } \\
\text { insulin } \\
\text { (s.c.) }+ \text { short-acting } \\
\text { insulin (i.v.) }\end{array}$ & $\begin{array}{l}\text { Subcutaneous } \\
+ \text { Intravenous }\end{array}$ & $\begin{array}{c}\text { Schwabing Insulin } \\
\text { Prophylaxis Trial } \\
\text { (Phase I) }\end{array}$ & At risk & Suggestive of efficacy & {$[40]$} \\
\hline Protein & Insulin & $\begin{array}{l}\text { Ultralente insulin } \\
\text { (s.c.) }+ \text { short-acting } \\
\text { insulin (i.v.) }\end{array}$ & $\begin{array}{l}\text { Subcutaneous } \\
+ \text { Intravenous }\end{array}$ & $\begin{array}{l}\text { DPT-1 Parenteral } \\
\text { arm (Phase III) }\end{array}$ & At risk & No effect & {$[41]$} \\
\hline Protein & Insulin & Ultralente insulin & Subcutaneous & EPPSCIT (Phase II) & At risk & No effect & {$[42]$} \\
\hline Protein & Insulin & Short-acting insulin & Oral & ORALE (Phase II) & $\begin{array}{l}\text { Recent-onset } \\
\text { T1D }\end{array}$ & No effect & {$[46]$} \\
\hline Protein & Insulin & Short-acting insulin & Oral & $\begin{array}{l}\text { IMDIAB VII } \\
\text { (Phase II) }\end{array}$ & $\begin{array}{l}\text { Recent-onset } \\
\text { T1D }\end{array}$ & No effect & {$[47]$} \\
\hline Protein & Insulin & Short-acting insulin & Oral & $\begin{array}{l}\text { DPT-1 Oral arm } \\
\text { (Phase III) }\end{array}$ & At risk & $\begin{array}{l}\text { Some efficacy in } \mathrm{IAA}^{+} \\
\text {subjects }\end{array}$ & {$[49]$} \\
\hline Protein & Insulin & Short-acting insulin & Oral & $\begin{array}{l}\text { Oral insulin } \\
\text { tolerance } \\
\text { (Phase III) }\end{array}$ & $\begin{array}{l}\text { Recent-onset } \\
\text { T1D }\end{array}$ & $\begin{array}{c}1 \mathrm{mg} \text { improved } \\
\text { C-peptide responses in } \\
\text { older patients; } 10 \mathrm{mg} \\
\text { accelerated C-peptide } \\
\text { decline in younger } \\
\text { patients }\end{array}$ & {$[48]$} \\
\hline Protein & Insulin & Short-acting insulin & Oral & $\begin{array}{l}\text { NIH/ADA/JDRF } \\
\text { oral insulin } \\
\text { (Phase III) }\end{array}$ & At-risk IAA ${ }^{+}$ & Ongoing & $\begin{array}{c}\text { NCT } \\
00419562\end{array}$ \\
\hline Protein & Insulin & Short-acting insulin & Intranasal & INIT-I (Phase I) & At-risk $\mathrm{IAA}^{+}$ & $\begin{array}{c}\text { Increase in aAb and } \\
\text { decrease in } \mathrm{T} \text {-cell } \\
\text { proliferative responses } \\
\text { to insulin }\end{array}$ & {$[50]$} \\
\hline Protein & Insulin & Short-acting insulin & Intranasal & DIPP (Phase III) & At risk & No effect & {$[51]$} \\
\hline Protein & Insulin & Short-acting insulin & Intranasal & $\begin{array}{l}\text { Intranasal insulin in } \\
\text { T1D patients } \\
\text { (Phase II) }\end{array}$ & $\begin{array}{c}\text { Recent-onset, } \\
\text { non-insulin- } \\
\text { dependent } \\
\text { T1D }\end{array}$ & $\begin{array}{l}\text { No effect; decrease in } \\
\text { IFN- } \gamma \text { T-cell responses } \\
\text { to PI; decrease in } \mathrm{Ab} \\
\text { responses to exogenous } \\
\text { insulin }\end{array}$ & {$[52]$} \\
\hline Protein & Insulin & Short-acting insulin & Intranasal & INIT-II (Phase II) & $\begin{array}{l}\text { At risk with } \\
\text { preserved 1st } \\
\text { phase insulin } \\
\text { response }\end{array}$ & Ongoing & $\begin{array}{c}\text { NCT } \\
00336674\end{array}$ \\
\hline Protein & Insulin & Short-acting insulin & $\begin{array}{l}\text { Oral or } \\
\text { Intranasal }\end{array}$ & Pre-POINT & $\begin{array}{l}\mathrm{IAA}^{-} \text {chidren } \\
\text { at high genetic } \\
\text { risk for T1D }\end{array}$ & Planned & {$[123]$} \\
\hline Protein & GAD & $\begin{array}{l}\text { Recombinant GAD } \\
\text { in alum (Diamyd) }\end{array}$ & Subcutaneous & $\begin{array}{c}\text { Swedish Diamyd } \\
\text { (Phase II) }\end{array}$ & $\begin{array}{l}\text { Recent-onset } \\
\text { T1D }\end{array}$ & $\begin{array}{c}\text { Slower decline in } \\
\text { fasting and stimulated } \\
\text { C-peptide secretion; } \\
\text { increase in anti-GAD } \\
\text { aAbs and in FowP3 and } \\
\text { TGF- } \beta \text { mRNA }\end{array}$ & {$[32]$} \\
\hline
\end{tabular}


Table 1: Continued.

\begin{tabular}{|c|c|c|c|c|c|c|c|}
\hline $\begin{array}{l}\text { Antigen } \\
\text { type }\end{array}$ & Antigen & Formulation & Route & Trial (Phase) & Subjects & $\begin{array}{l}\text { Outcome and/or } \\
\text { immune biomarkers }\end{array}$ & Reference \\
\hline Protein & GAD & $\begin{array}{l}\text { Recombinant GAD } \\
\text { in alum (Diamyd) }\end{array}$ & Subcutaneous & $\begin{array}{l}\text { EU Diamyd } \\
\text { (Phase III) }\end{array}$ & $\begin{array}{l}\text { Recent-onset } \\
\text { T1D }\end{array}$ & Ongoing & $\begin{array}{c}\text { NCT } \\
00723411\end{array}$ \\
\hline Protein & GAD & $\begin{array}{l}\text { Recombinant GAD } \\
\text { in alum (Diamyd) }\end{array}$ & Subcutaneous & $\begin{array}{c}\text { US Diamyd } \\
\text { (DIAPREVENT) } \\
\text { (Phase III) }\end{array}$ & $\begin{array}{l}\text { Recent-onset } \\
\text { T1D }\end{array}$ & Ongoing & $\begin{array}{c}\text { NCT } \\
00751842\end{array}$ \\
\hline Protein & GAD & $\begin{array}{l}\text { Recombinant GAD } \\
\text { in alum }\end{array}$ & Subcutaneous & $\begin{array}{l}\text { NIDDK/ADA/JDRF } \\
\text { GAD-alum } \\
\text { (Phase II) }\end{array}$ & $\begin{array}{l}\text { Recent-onset } \\
\text { T1D }\end{array}$ & Ongoing & $\begin{array}{c}\text { NCT } \\
00529399\end{array}$ \\
\hline Protein & GAD & $\begin{array}{l}\text { Recombinant GAD } \\
\text { in alum (Diamyd) }\end{array}$ & Subcutaneous & $\begin{array}{l}\text { DIAPREV-IT } \\
\text { (Phase II) }\end{array}$ & $\begin{array}{l}\text { At risk, GAD } \\
\mathrm{aAb}^{+}+\geq 1 \\
\text { other } \mathrm{aAb}\end{array}$ & Ongoing & $\begin{array}{c}\text { NCT } \\
01122446\end{array}$ \\
\hline Peptide & Insulin & $\begin{array}{l}\text { Insulin B chain in } \\
\text { incomplete Freund's } \\
\text { adjuvant }\end{array}$ & Intramuscular & $\begin{array}{l}\text { IBC-VS01 } \\
\text { (Phase I) }\end{array}$ & $\begin{array}{l}\text { Recent-onset } \\
\text { IAA }^{+} \mathrm{T} 1 \mathrm{D}\end{array}$ & $\begin{array}{l}\text { Increased TGF- } \beta \\
\text { production }\end{array}$ & {$[66]$} \\
\hline Peptide & Proinsulin & $\mathrm{PI}_{\mathrm{C} 19-\mathrm{A} 3}$ & Intradermal & $\begin{array}{c}\text { PI peptide } \\
\text { immunotherapy } \\
(\text { Phase I })\end{array}$ & $\begin{array}{l}\text { Long-standing } \\
\text { T1D }\end{array}$ & $\begin{array}{l}\text { Transient PI-specific } \\
\text { IL-10 secretion in } 3 / 18 \\
\text { patients at } 30 \mu \mathrm{g}\end{array}$ & {$[67]$} \\
\hline $\begin{array}{l}\text { Modified } \\
\text { peptide }\end{array}$ & Insulin & $\begin{array}{l}\text { NBI-6024 } \\
\left(\mathrm{B}_{9-23} \mathrm{APL}\right)\end{array}$ & Subcutaneous & $\begin{array}{l}\text { NBI-6024-0003 } \\
\quad(\text { Phase I) }\end{array}$ & $\begin{array}{l}\text { Recent-onset } \\
\text { T1D }\end{array}$ & $\begin{array}{l}\text { Shift from Th1 to Th2 } \\
\text { responses }\end{array}$ & [76] \\
\hline $\begin{array}{l}\text { Modified } \\
\text { peptide }\end{array}$ & Insulin & $\begin{array}{l}\text { NBI-6024 } \\
\left(B_{9-23} \mathrm{APL}\right)\end{array}$ & Subcutaneous & $\begin{array}{l}\text { Neurocrine } \\
\text { NBI-6024 } \\
\text { (Phase II) }\end{array}$ & $\begin{array}{l}\text { Recent-onset } \\
\text { T1D }\end{array}$ & No effect & [77] \\
\hline $\begin{array}{l}\text { Modified } \\
\text { protein }\end{array}$ & Insulin & $\begin{array}{l}\text { Insulin-coupled } \\
\text { ECDI-fixed } \\
\text { autologous } \\
\text { leukocytes }\end{array}$ & $?$ & $\begin{array}{l}\text { ITN insulin-coupled } \\
\text { leukocytes }\end{array}$ & At risk & Planned & {$[86]$} \\
\hline $\begin{array}{l}\text { DNA } \\
\text { plasmid }\end{array}$ & Proinsulin & $\begin{array}{l}\text { BHT-3021 } \\
\text { (PI plasmid) }\end{array}$ & Intramuscular & $\begin{array}{l}\text { Bayhill BHT-3021 } \\
\text { (Phase I) }\end{array}$ & $\begin{array}{l}\text { Recent-onset } \\
\text { T1D }\end{array}$ & Ongoing & $\begin{array}{c}\text { NCT } \\
00453375\end{array}$ \\
\hline $\begin{array}{l}\text { Ag- } \\
\text { specific } \\
\text { cell } \\
\text { therapy }\end{array}$ & None & $\begin{array}{c}\text { Autologous } \\
\text { monocyte-derived } \\
\text { DCs treated with } \\
\text { CD40/CD80/CD86 } \\
\text { antisense } \\
\text { oligonucleotides }\end{array}$ & Intradermal & $\begin{array}{c}\text { Pittsburgh DC } \\
\text { vaccine (Phase I) }\end{array}$ & $\begin{array}{l}\text { Long-standing } \\
\text { T1D }\end{array}$ & Ongoing & $\begin{array}{c}\text { NCT } \\
00445913\end{array}$ \\
\hline
\end{tabular}

median of 4.3 years. Also, in this case, no significant protection was induced, in line with the negative results of smaller trials [46-48]. However, analysis of a subgroup positive for IAA suggested a potential benefit, as the annualized T1D rate was $6.2 \%$ with oral insulin and $10.4 \%$ with placebo [49]. It is possible that the intervention may be more effective in these individuals due to a more active autoimmunity against insulin. This observation has prompted a new oral insulin trial focused on IAA+ at-risk subjects (ClinicalTrials.gov NCT00419562). It also underlines the importance of a through autoimmunity profiling to optimize enrollment (see below).

Similar prevention and intervention trials using intranasal insulin administration proved safe but did not yield significant T1D protection [50-52]. One further prevention trial is ongoing (ClinicalTrial.gov NCT00336674). Interestingly, no study has so far tried to administer PI rather than insulin. This could be attractive for a number of reasons. First, PI has a much lower affinity for the insulin receptor. Although it could be degraded into insulin once administered, the window of safe doses not engendering hypoglycemia could be wider. Second, a number of critical epitopes have been described which are specific of PI, as they reside either in the $C$ peptide or at its junction with the $B$ chain $[19,53]$. Important epitopes have also been described which are specific of PPI, as they lie in the leader sequence $[19,34,54]$. Although PPI is more difficult to produce due to its lower solubility in water, this characteristic could be even advantageous to obtain a depot effect once injected subcutaneously.

6.2. $G A D$. In a recent intervention trial, Ludvigsson et al. treated new-onset $(<18 \mathrm{mo})$ T1D children positive for antiGAD aAbs with two subcutaneous injections of GAD $(20 \mu \mathrm{g})$ or placebo in alum adjuvant and followed this children for 30 months. Although there was no change in insulin 

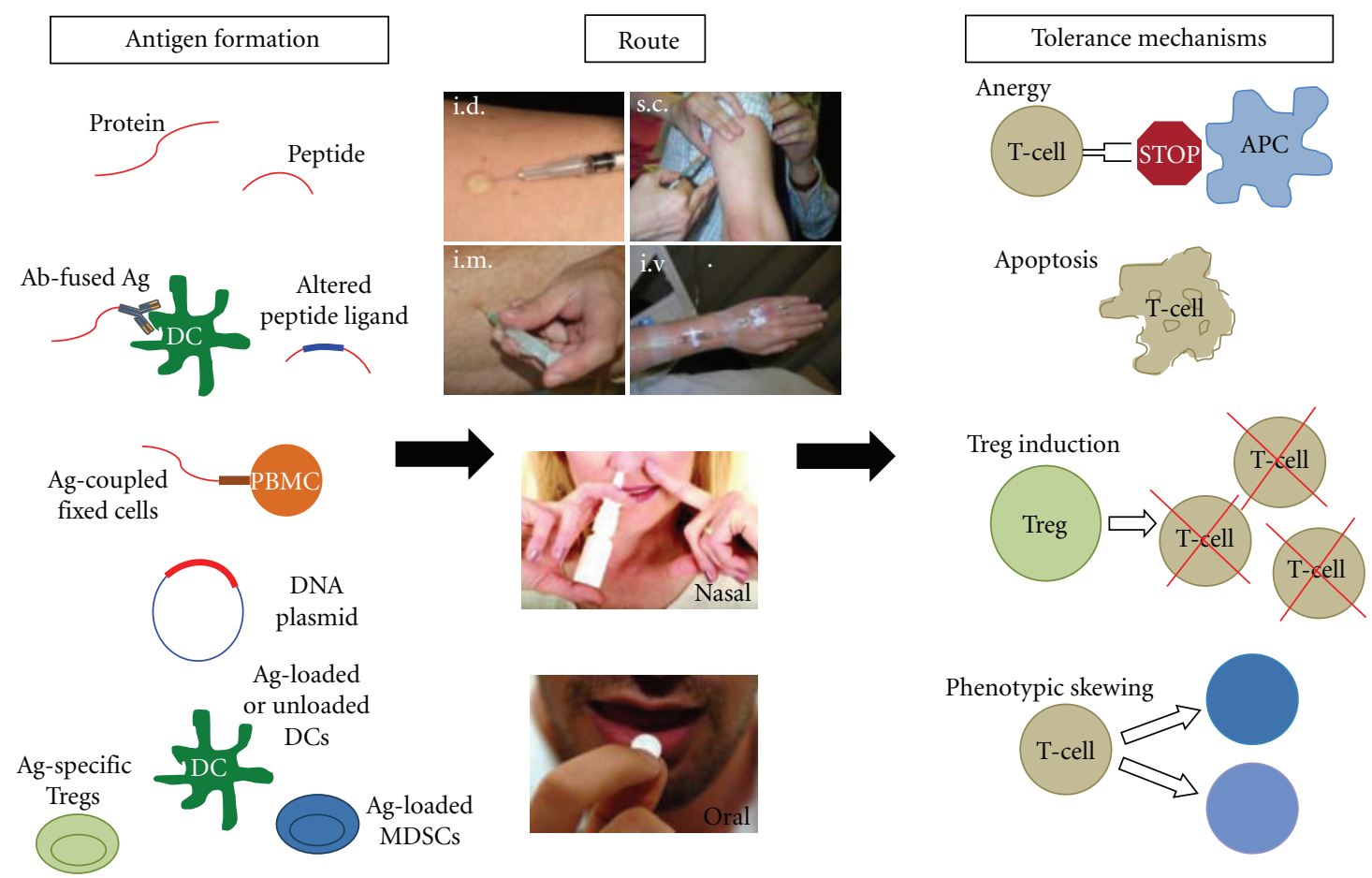

Figure 2: Ag-specific immune therapies. Different Ag formulations can be administered via different routes, triggering various tolerance mechanisms. APC: Ag-presenting cell; DC: dendritic cell; i.d.: intradermal; i.m., intramuscular; i.v.: intravenous; MDSCs: myeloid-derived suppressor cells; PBMC: peripheral blood mononuclear cell; s.c.: subcutaneous; Tregs: regulatory T cells.

requirements, there was a slower decline in the fasting and stimulated C-peptide secretion (a common measure of residual $\beta$-cell function). Importantly, this effect was observed only in those patients treated within 6 months of diagnosis. Similar observations have been made in other clinical trials, such as the European anti-CD3 trial, where lower insulin requirements were observed only in those patients who had higher residual $\beta$-cell function at the time of enrollment [55]. Taken together, they suggest that "the earlier the better," and that interventions at a preclinical stage would be much more beneficial.

In the GAD trial, the effect on C-peptide secretion was accompanied by an increase in anti-GAD aAb titers and in mRNA expression of FoxP3 and transforming growth factor (TGF) $-\beta$ in peripheral blood mononuclear cells, which could suggest a regulatory switch. It may be counter-intuitive that the GAD vaccine is administered along with an alum adjuvant, which is known to favor immunogenic rather than tolerogenic responses, especially with the "primeboost" strategy used in this trial. This peculiarity may raise the possibility that the therapeutic effect may be due, at least in part, to the high titers of anti-GAD Abs induced after vaccination [56]. Indeed, a protective effect of antiislet aAbs has been evoked to explain the lower T1D risk observed in the offspring of $\mathrm{aAb}+\mathrm{T} 1 \mathrm{D}$ mothers compared to $\mathrm{aAb}$-negative ones [57]. Alternative strategies using GAD vaccination in the absence of adjuvant would be equally worth testing. Larger intervention trials using the GAD alum preparation are in progress in Europe and US and will allow to validate the effect on C-peptide secretion and to further explore its immune correlates (ClinicalTrials.gov NCT00723411, NCT00751842, and NCT00529399). A prevention trial is also in progress in Sweden (NCT01122446).

\section{Peptides}

Peptides have the significant edge of being easier to synthesize at high purity than recombinant proteins. Long peptides may have the advantage of covering multiple epitopes, thus targeting different T-cell specificity. Moreover, the use of long peptides requires processing before loading on HLA molecules. This requirement may allow some selectivity in the Ag-presenting cells targeted, as only professional Ag-presenting cells-most notably immature, tolerogenic dendritic cells_can efficiently process and present exogenous peptides. However, there are also multiple drawbacks compared to protein Ags. First, although peptides are smaller molecules and thus deliver up to 50 times more agent on a weight-for-weight basis when compared with protein Ags, the life span of peptides in blood-and likely in other tissues-is very short, in the order of minutes [58]. Second, peptides (but also epitopes processed from protein Ags) may be presented in alternative ways, thus triggering unwanted T-cell activation $[59,60]$. Third, the same peptide dose can trigger diverse effects on different $\mathrm{T}$ cells, depending on their relative Ag avidity (e.g., simple activation versus activationinduced apoptosis) [61, 62]. Fourth, activation-induced 
apoptosis, which is one of the mechanisms through which peptides may work, develops through a phase of deleterious activation before driving $\mathrm{T}$ cells to death. The drawbacks of this type of peptide-based approaches are exemplified by the disappointing results obtained on multiple sclerosis patients. Two clinical trials were prematurely terminated because of disease flare-ups rather than remissions [63-65]. Although these trials employed altered peptide ligands (see below), the same caveats may apply to native peptides.

There is no sufficient hindsight from T1D clinical trials to judge whether these theoretical hurdles are encountered. In a Phase I study on 12 new-onset T1D patients, a single intramuscular administration of insulin $\mathrm{B}$ chain (i.e., a 30-amino-acid polypeptide) or placebo in incomplete Freund's adjuvant was safe and induced robust insulinspecific humoral and T-cell responses but no difference in stimulated C-peptide responses. Given the small sample size and patients' recruitment irrespective of residual C-peptide secretion, it is not possible to draw conclusions concerning clinical efficacy. However, B-chain-stimulated CD4+ T cells from B-chain-treated patients exhibited higher TGF$\beta$ secretion in the first 3 months after treatment as compared to $\mathrm{T}$ cells from placebo-treated patients, yielding clones with profiles suggestive of a regulatory phenotype [66].

A Phase I clinical trial with a $\mathrm{DR}^{*} 04$ :01-restricted PI peptide C19-A3 in long-standing ( $>5$ years) T1D patients has also been reported [67]. This trial employed intradermal administration at a dose of 30 or $300 \mu \mathrm{g}$ repeated 3 times within 2 months, enrolling 18 patients in each arm (peptide versus no treatment). The therapy was well tolerated and did not induce proinflammatory reactivation of PI-specific $\mathrm{T}$ cells, but rather transient PI-specific IL-10 secretion in 3 of the 18 patients treated at the lower dose. As is the case for Phase I trials, the aim of this study was to assess safety and not clinical efficacy, and the inclusion criteria reflect this rationale (long-standing T1D patients with glucagon-stimulated $C$ peptide $\leq 0.2 \mathrm{nmol} / \mathrm{L}$; control group left untreated, i.e., no placebo). Although the observed safety profile is reassuring, it should be noted that PI-specific T-cell responses were not detectable at baseline in these long-standing patients, contrary to what previously observed in new-onset ones [68]. Thus, the effect of peptide administration may be different in the presence of recently in vivo primed PI-specific T cells and of a higher residual $\beta$-cell mass.

Clinical trials with a peptide derived from the heat-shock protein (hsp60) immunodominant epitope 437-460 (DiaPep277) showed marginally preserved endogenous insulin production in some newly diagnosed T1D patients $[69,70]$. The mechanism by which the DiaPep277 may function is not completely understood. Qualifying hsp60 as a target Ag in T1D autoimmunity is debatable, and alternative, non-Agspecific mechanisms are possible. Indeed, hsp60 has been shown to activate $\mathrm{T}$ cells via the Toll-like receptor 2 and to inhibit T-cell chemotaxis [71]. This pathway could also induce the shift from $\mathrm{T}$ helper (Th) 1 to $\mathrm{Th} 2$ cytokines observed in humans. Thus, this mode of action would categorize DiaPep277 as a systemic rather than an Ag-specific immune modulator.

\section{Modified Protein and Peptide Ags}

Disarming pathogenic $\mathrm{T}$ cells by modifying the epitopes they recognize at key amino acid positions is an option that has been sought in several autoimmune diseases. TCR interaction with these modified epitopes, called altered peptide ligands (APLs), can result in only partial activation and dramatically different T-cell phenotypes, ranging from inducing selective stimulatory functions to completely turning off their functional capacity [72]. The central role of the insulin $\mathrm{B}_{9-23}$ epitope in the NOD mouse $[23,73]$ and its immunodominance in T1D patients [74] led to develop an APL version called NBI-6024. This $\mathrm{B}_{9-23}$ APL showed promising results in NOD mice [75]. Results of a Phase I clinical study on recent-onset T1D patients suggested that NBI-6024 treatment shifted Th1 responses to a Th2 phenotype [76]. However, a subsequent Phase II, dose-ranging trial testing repeated NBI-6024 subcutaneous treatment at 0.1 , 0.5 , or $1 \mathrm{mg}$ did not preserve $\beta$-cell function [77]. Clinical trials with APLs in multiple sclerosis further chilled down enthusiasm for this approach. Two Phase II trials with a myelin basic protein APL were prematurely terminated, as treatment led to disease exacerbations and hypersensitivity reactions $[63,64]$. This dramatic experience underlines the difficulty of developing one single APL which would induce the same effect on all cognate T cells. It is possible that the APL effect may be dependent on parameters such as effect-ive dose delivered and T-cell avidity, activation status and phenotype, and thus trigger different polarizing signals [65].

As DCs present Ags in a tolerogenic manner in the steady state, for example, in the absence of infection or inflammation, selective Ag delivery to DCs promotes tolerance in the absence of maturation stimuli [78-80]. To this end, a number of mAbs against endocytic receptors expressed by DCs have been developed, with the aim of using them to target $\mathrm{Ag}$ delivery. DEC-205 (CD205) is one of such receptors, which is expressed on the CD8+ DC subset capable to efficiently cross-present [81]. Besides selective targeting, this in vivo Ag delivery approach would obviate the need for leukapheresis and ex vivo DC manipulation. On these grounds, the group of T. DiLorenzo delivered the IGRP mimotope NRP-V7 in vivo to murine DCs by fusing it with an anti-DEC-205 mAb. Proliferation of transferred NRP-V7-specific T cells was initially observed, but this was followed by deletion. Tolerance was achieved because rechallenge of mice with NRP-V7 in adjuvant did not induce an immune response. NRP-V7 delivery through DEC-205 was tolerogenic only when performed in the steady state. As expected, coadministration of anti-CD40 mAb and polyI:C to mature DCs led instead to enhanced expansion of transferred T cells [82]. Although evidence of T1D protection is still missing, this approach may prove of great interest when combined with suitable epitopes. Moving towards this direction, the feasibility of DEC-205 delivery of the entire PPI molecule is 
under investigation [83]. This would facilitate translation to patients expressing diverse MHC molecules.

Another original system of tolerogenic Ag delivery has been developed by Miller and coworkers [84-86]. This consists in administration of self peptides covalently cross-linked to cells via ethylene carbodiimide (ECDI). In preclinical models of various autoimmune diseases, this approach involves ECDI cross-linking of self proteins or peptides to syngeneic splenocytes. Intravenous injection of these Ag-coupled splenocytes is highly effective at inducing tolerance for both prevention and treatment of various autoimmune diseases in mouse models, including experimental autoimmune encephalomyelitis (a mouse model of multiple sclerosis) [87] and T1D in the NOD mouse [88]. Ag-coupled splenocytes behave like apoptotic bodies and are rapidly uptaken by Ag-presenting cells, much more efficiently than soluble protein or peptide Ags [89]. Ag presentation leads to tolerance induction by inducing Ag-specific T-cell unresponsiveness via two synergistic mechanisms: programmed death (PD)-1/PD ligand 1-mediated anergy and T regulatory cell (Treg) activation [88]. Processing and presentation of Ags coupled to apoptotic bodies gives the advantage of inducing tolerance by cellular carriers fixed with peptides, intact proteins, or even crude homogenates of the target organ [87]. This tolerogenic system is currently being tested in multiple sclerosis, using ECDI-fixed autologous peripheral blood leukocytes coupled with a cocktail of seven myelin peptides. A similar trial using insulin-coupled autologous leukocytes for prevention of T1D is under development by the Immune Tolerance Network.

\section{DNA Plasmids}

DNA vaccines are the simplest embodiment of vaccines that, rather than consisting of the Ag itself, provide genes for endogenous synthesis of the protein Ag. The idea stemmed from the need to efficiently deliver protein and polypeptide Ags to the MHC Class I pathway for presentation to and stimulation of CD8+ T-cell responses. Inducing such responses with exogenous protein Ags is not efficient, as it requires cross-presentation, a requirement which can be fulfilled mostly if not exclusively by specialized DC subsets. As DNA-encoded Ags are endogenously translated by transfected cells, DNA immunization has the potential to result in conventional priming as well as cross-priming.

There are many ways to efficiently deliver DNA vaccines [90], and this strategy has been exploited for many research applications such as T-cell epitope identification [91, 92]. One strategy consists of bombarding the epidermis with gold microbeads coated with plasmid, which can directly transfect Langerhans cells causing their rapid migration to draining lymph nodes. Alternatively, plasmids can be intramuscularly injected, leading to predominant transfection of myocytes and less efficient $\mathrm{Ag}$ presentation. This latter approach is currently been explored for tolerance induction, using a plasmid encoding for proinsulin (BHT-3021) in T1D patients with less than 5 years of disease (ClinicalTrials.gov NCT00453375). The relatively long disease duration used for patient recruitment and the low potency of DNA vaccines documented in other clinical trials may be important factors in the final outcome.

\section{Ag-Specific Cell Therapies}

Ag-specific tolerance restoration could be induced not only by using suitable Ag proteins or peptides, but also by adoptively transferring cells armed to be selective for the targets of choice. These approaches are being explored for Tregs and DCs [93].

Expansion protocols to obtain high numbers of CD4+ Tregs suitable for in vivo cell therapies have been developed for both mouse and human [94-97]. However, these cells remain polyclonal in nature although a shortcut has been obtained in murine models by expanding $\mathrm{T}$ cells from mice transgenic for a T-cell receptor which recognizes a specific $\beta$-cell epitope such as BDC2.5. Although some pioneering reports of expanded human $\beta$-cell Ag-specific Tregs have been published [98, 99], it is not clear whether these cells would have suitable characteristics to exert therapeutic effects once transferred in vivo. Further incertitude is added by a recent paper describing that polyclonal murine CD4+ Tregs can revert their phenotype after in vivo transfer, losing FoxP3 expression and acquiring pathogenic potential. Indeed, these "ex-Tregs" were found to accumulate spontaneously in the insulitis of NOD mice, suggesting that this phenomenon may not be peculiar of transfer settings. Even more worryingly, these ex-Tregs were capable of efficiently transferring disease, similar to standard T effector cells [100].

Another cell-based approach consists of loading immature DCs with the Ag of interest. This type of approach has previously been shown to be efficient at promoting Agspecific immune tolerance $[101,102]$. This strategy is now being tested for T1D intervention in a Phase I safety study led by M. Trucco. Tolerogenic autologous monocyte-derived DCs are being generated by treating them ex vivo with antisense oligonucleotides targeting the CD40, CD80, and CD86 costimulatory molecules [103]. These modified DCs are being compared with control autologous monocyte-derived DCs left untreated. The fact that intravenously administered bone-marrow-derived DCs accumulate predominantly in the spleen and the pancreatic and tracheal lymph nodes [104] justifies the choice of not loading these DCs with exogenous Ag. These DCs may acquire islet Ags in vivo in pancreatic lymph nodes and could thus modulate effector and regulatory T-cell responses to T1D-relevant Ags even without deliberate prior Ag loading. The other peculiarity of this trial is that DCs (which are not used fresh but cryopreserved) will be administered intradermally closest to the physical location of the pancreas, as both sites may drain to the same lymph nodes (ClinicalTrials.gov NCT00445913). Importantly, preclinical studies suggest that the therapeutic effect of these unloaded tolerogenic DCs remains Ag-specific, as splenic T cells from treated mice proliferated to allo-Ags ex vivo [103].

Another cell population which may soon be tested for cell-based immunotherapy is myeloid-derived suppressor 


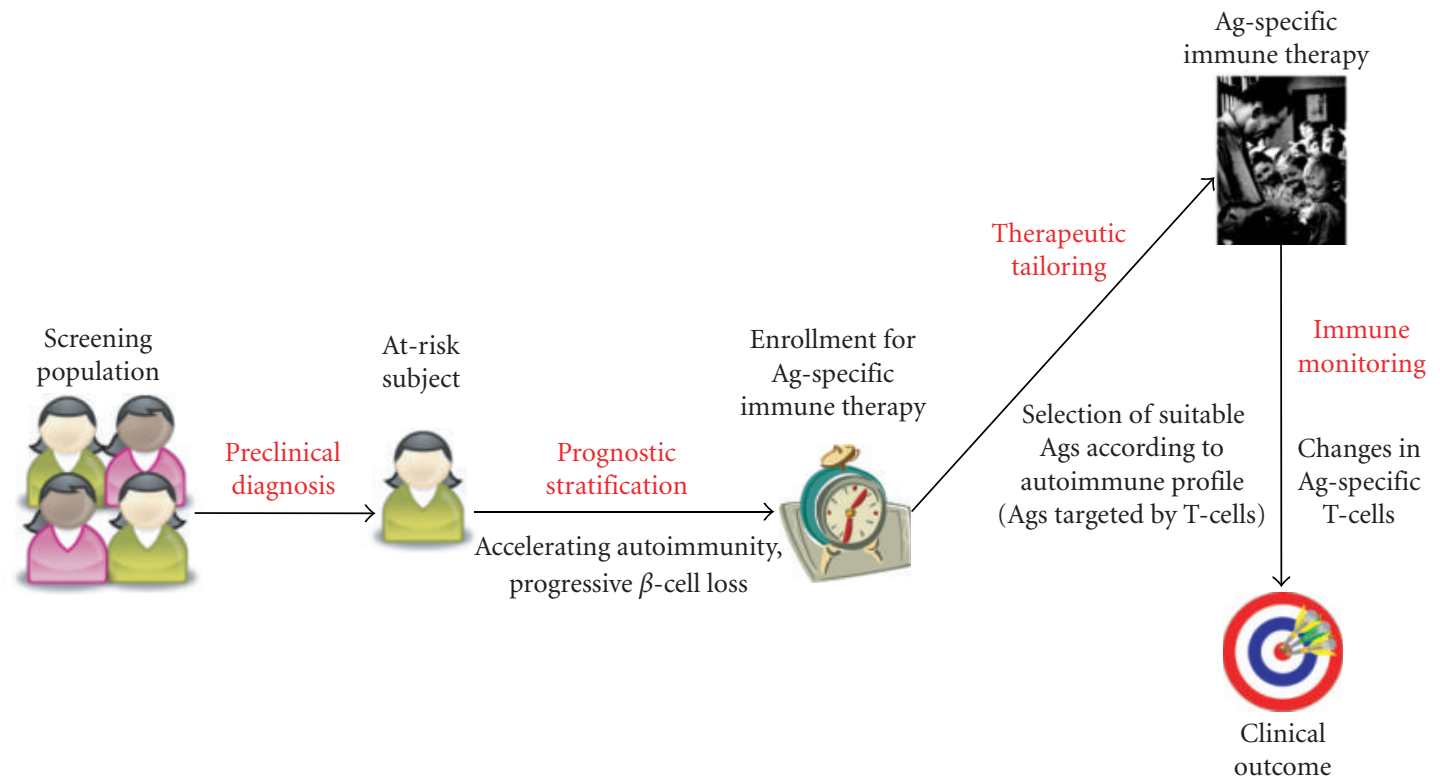

FIGURE 3: "Immune staging" of T1D. Biomarkers of $\beta$-cell autoimmunity such as aAbs and T cells could help to identify at-risk subjects at an early stage (preclinical diagnosis) and to follow them up over time to decide the need for immune therapy and the best timing for treatment (prognostic stratification). Ag-specific immune therapy could be personalized for each subject by administering therapeutic formulations of those Ags targeted by aAb and/or T-cell responses. Modifications induced on such responses could be followed in real time during treatment, thus allowing to assess immune efficacy prior to and independent of clinical outcome.

cells (MDSCs). These are cells of myeloid origin with immunoregulatory activity that can suppress Ag-specific and nonspecific T-cell responses via different mechanisms in cancer [105-107], transplantation [108], and T1D [109]. Pre-clinical study testing the protective role of these cells in T1D were performed in RIP-HA mice transferred with HAspecific CD4+ T cells, where it was shown that HA-loaded MDSCs could act as APCs in an Ag-specific fashion to induce anergy of effector T cells, development of Tregs, and T1D prevention [109].

\section{The Importance of Immune Surrogate Markers}

In light of the formidable challenge of rescuing a significant $\beta$-cell mass in already diabetic patients, it is important to evaluate not only clinical (lower HbAlc values and reduced insulin requirements) and metabolic (C-peptide secretion) endpoints, but also immune surrogate endpoints. This is even more important in trials not showing clinical benefit, or not poised to detect such benefits, as is commonly the case for phase I studies. Indeed, the lack of clinical effects could be open to disparate interpretation, including late treatment in front of full-blown disease, the need to target multiple Ags in advanced T1D once epitope spreading has occurred, or failure to restore immune tolerance. These possibilities can be sorted out by immune monitoring analyses performed before, during, and after treatment, particularly by scrutinizing changes induced in T-cell responses specific to the administered Ag (Figure 3). Validation and standardization of blood sample processing and T-cell assay procedures is an important goal to this end [110-112].

We recently reported a proof-of-concept study on $\mathrm{aAb}+$ diabetic patients not requiring insulin at the time of diagnosis. These patients were treated with intranasal insulin in an attempt to save residual $\beta$ cells. Although nasal insulin treated patients eventually progressed towards insulin dependency at a rate similar to placebo-treated ones, we could document successful induction of insulin-specific immune tolerance both at the T-cell and antibody level [52]. Contrary to what observed in the placebo arm, patients treated with intranasal insulin displayed significant reductions in frequencies of interferon- $\gamma$-secreting PI-specific Tcell responses, using high sensitivity $\mathrm{T}$-cell assays that amplify responses by means of an accelerated cocultured DC (acDC) stimulation (Martinuzzi et al., under revision). This effect was Ag-specific, as it was not observed for responses towards the tetanus toxoid recall Ag. The initiation of insulin therapy further documented that this PI-specific tolerance was operational in vivo, as intranasal insulin treated subjects failed to develop anti-insulin antibodies [52]. These results suggest that this intervention is immunological effective, but not sufficient to rescue $\beta$ cells, probably because administered too late, at an advanced stage where most islets have already disappeared and $\beta$-cell autoimmunity has already spread too far on additional Ag specificities. Knowing whether Ag-specific T-cell responses are modified and in which individuals provides key mechanistic information to plan further trials and modify therapeutic strategies accordingly. This information may also be critical to optimize enrollment strategies. Indeed, pretreatment testing for $\mathrm{T}$-cell reactivities 
could allow to focus enrollment on those patients displaying active insulin-specific autoimmune responses, as there might be little benefit in treating those who do not harbor such responses (Figure 3 ). Imaging techniques allowing to visualize $\beta$-cell mass and infiltration will provide additional tools for immune-based pretreatment staging and posttreatment monitoring [113].

\section{Combination Therapies}

Despite the mentioned evidence in the NOD mouse for an initiating role of insulin as the primary $\beta$-cell $\mathrm{Ag}$ target, the same principle may not apply to outbred humans, due to the variable genetic and environmental background and the later timing of intervention and even prevention trials, at a stage where epitope spreading is likely to have occurred. Therefore, strategies where multiple $\beta$-cell Ags (e.g., PI and GAD) are combined may yield synergistic effects and more substantial clinical benefit. This possibility will certainly be explored in upcoming clinical trials. Another option under consideration consists of combining Ags with immune modulatory mAbs such as anti-CD3 and anti-CD20, which have already been trialed alone, sometimes with encouraging results [114]. Besides the potential for synergy, this approach may allow to reduce $\mathrm{mAb}$ dosing, thus limiting unwanted side effects and facilitating repeated treatment [115-117]. Combination of tolerogenic strategies with approaches aimed at replacing $[118,119]$ or regenerating $[120] \beta$ cells are also attractive, as they may allow to intervene at later stages. Although a first clinical trial testing exenatide alone or in combination with daclizumab did not show any effect [121], other agents and combinations thereof need to be tested before drawing definite conclusions.

\section{Conclusions}

We are moving towards a new era of clinical trials in T1D, where the long-sought goal of Ag-specific immune tolerance is becoming at reach. To turn these promises into reality, it will be important to comparatively evaluate several aspects that remain poorly defined. (1) Administration routes: intravenous, subcutaneous, intradermal, and mucosal. Regarding the latter, it is surprising that only oral and intranasal routes have been investigated for T1D, leaving out the sublingual approach despite its successful track record for allergy desensitization [122]. (2) Ag dose, identifying suitable therapeutic ranges, which will critically depend on the nature of the $\mathrm{Ag}$ and the route of administration. We have discussed the hurdles of translating the insulin doses used in NOD mouse studies into clinical trials. Importantly, difference insulin formulations may widen the therapeutic window. Another key difference between preclinical and human studies is the timing of intervention. A proposed primary prevention trial (Pre-POINT) [123] aims to address this issue of disease stage by intervening with oral or nasal insulin in children genetically predisposed to T1D, before the appearance of the first signs of $\beta$-cell autoimmunity (i.e., in children who have not yet developed IAA). (3)
Frequency and interval of administration, keeping in mind that approaches promoting longer persistence of low $\mathrm{Ag}$ loads may be beneficial over high-load spikes [43]. Ancillary mechanistic studies should accompany these trials to clarify modes of action and help optimizing the risk-to-benefit ratio. Autoimmune T-cell profiling may be particularly useful for tailoring and monitoring treatment in each individual patient.

\section{Acknowledgment}

Research performed in the Laboratory was supported by the Juvenile Diabetes Research Foundation (JDRF Grant no. 12008-106). R. Mallone is an INSERM Avenir Investigator.

\section{References}

[1] J. Mestas and C. C. W. Hughes, "Of mice and not men: differences between mouse and human immunology," Journal of Immunology, vol. 172, no. 5, pp. 2731-2738, 2004.

[2] S. Sreenan, A. J. Pick, M. Levisetti, A. C. Baldwin, W. Pugh, and K. S. Polonsky, "Increased $\beta$-cell proliferation and reduced mass before diabetes onset in the nonobese diabetic mouse," Diabetes, vol. 48, no. 5, pp. 989-996, 1999.

[3] W. Gepts, "Pathologic anatomy of the pancreas in juvenile diabetes mellitus," Diabetes, vol. 14, no. 10, pp. 619-633, 1965.

[4] A. K. Foulis, M. A. Farquharson, and R. Hardman, "Aberrant expression of Class II major histocompatibility complex molecules by B cells and hyperexpression of Class I major histocompatibility complex molecules by insulin containing islets in Type 1 (insulin-dependent) diabetes mellitus," Diabetologia, vol. 30, no. 5, pp. 333-343, 1987.

[5] A. K. Foulis, C. N. Liddle, and M. A. Farquharson, "The histopathology of the pancreas in Type I (insulin-dependent) diabetes mellitus: a 25-year review of deaths in patients under 20 years of age in the United Kingdom," Diabetologia, vol. 29, no. 5, pp. 267-274, 1986.

[6] D. J. Klinke, "Extent of beta cell destruction is important but insufficient to predict the onset of type 1 diabetes mellitus," PLoS ONE, vol. 3, no. 1, Article ID e1374, 2008.

[7] N. A. Sherry, E. B. Tsai, and K. C. Herold, "Natural history of $\beta$-cell function in type 1 diabetes," Diabetes, vol. 54, supplement 2, pp. S32-S39, 2005.

[8] E. Akirav, J. A. Kushner, and K. C. Herold, " $\beta$-cell mass and type 1 diabetes: going, going, gone?” Diabetes, vol. 57 , no. 11 , pp. 2883-2888, 2008.

[9] L. I. Wen, R. E. Ley, P. Y. U. Volchkov et al., "Innate immunity and intestinal microbiota in the development of Type 1 diabetes," Nature, vol. 455, no. 7216, pp. 1109-1113, 2008.

[10] S. Fourlanos, P. Narendran, G. B. Byrnes, P. G. Colman, and L. C. Harrison, "Insulin resistance is a risk factor for progression to Type 1 diabetes," Diabetologia, vol. 47, no. 10, pp. 1661-1667, 2004.

[11] G. Pagano, V. Tagliaferro, and Q. Carta, "Metformin reduces insulin requirement in Type 1 (insulin-dependent) diabetes," Diabetologia, vol. 24, no. 5, pp. 351-354, 1983.

[12] J. Hamilton, E. Cummings, V. Zdravkovic, D. Finegood, and D. Daneman, "Metformin as an adjunct therapy in adolescents with type 1 diabetes and insulin resistance: a randomized controlled trial," Diabetes Care, vol. 26, no. 1, pp. 138-143, 2003. 
[13] S. S. Lund, L. Tarnow, A. S. Astrup et al., "Effect of adjunct metformin treatment in patients with type-1 diabetes and persistent inadequate glycaemic control. A randomized study," PLoS ONE, vol. 3, no. 10, Article ID e3363, 2008.

[14] C. R. Stiller, J. Dupre, and M. Gent, "Effects of cyclosporine immunosuppression in insulin-dependent diabetes mellitus of recent onset," Science, vol. 223, no. 4643, pp. 1362-1367, 1984.

[15] P. A. Gottlieb, S. Quinlan, H. Krause-Steinrauf et al., "Failure to preserve $\beta$-cell function with mycophenolate mofetil and daclizumab combined therapy in patients with new-onset type 1 diabetes," Diabetes Care, vol. 33, no. 4, pp. 826-832, 2010.

[16] J. A. Bluestone, K. Herold, and G. Eisenbarth, "Genetics, pathogenesis and clinical interventions in type 1 diabetes," Nature, vol. 464, no. 7293, pp. 1293-1300, 2010.

[17] S. M. Lieberman and T. P. DiLorenzo, "A comprehensive guide to antibody and T-cell responses in type 1 diabetes," Tissue Antigens, vol. 62, no. 5, pp. 359-377, 2003.

[18] S. M. Lieberman, A. M. Evans, B. Han et al., "Identification of the $\beta$ cell antigen targeted by a prevalent population of pathogenic CD8+ T cells in autoimmune diabetes," Proceedings of the National Academy of Sciences of the United States of America, vol. 100, no. 14, pp. 8384-8388, 2003.

[19] R. Mallone, E. Martinuzzi, P. Blancou et al., "CD8+ T-cell responses identify $\beta$-cell autoimmunity in human type 1 diabetes," Diabetes, vol. 56, no. 3, pp. 613-621, 2007.

[20] K. Thébault-Baumont, D. Dubois-Laforgue, P. Krief et al., "Acceleration of type 1 diabetes mellitus in proinsulin 2deficient NOD mice," Journal of Clinical Investigation, vol. 111, no. 6, pp. 851-857, 2003.

[21] B. Faideau, C. Lotton, B. Lucas et al., "Tolerance to proinsulin-2 is due to radioresistant thymic cells," Journal of Immunology, vol. 177, no. 1, pp. 53-60, 2006.

[22] H. Moriyama, N. Abiru, J. Paronen et al., "Evidence for a primary islet autoantigen (preproinsulin 1) for insulitis and diabetes in the nonobese diabetic mouse," Proceedings of the National Academy of Sciences of the United States of America, vol. 100, no. 18, pp. 10376-10381, 2003.

[23] M. Nakayama, N. Abiru, H. Moriyama et al., "Prime role for an insulin epitope in the development of type 1 diabetes in NOD mice," Nature, vol. 435, no. 7039, pp. 220-223, 2005.

[24] D. Daniel, R. G. Gill, N. Schloot, and D. Wegmann, "Epitope specificity, cytokine production profile and diabetogenic activity of insulin-specific $\mathrm{T}$ cell clones isolated from NOD mice," European Journal of Immunology, vol. 25, no. 4, pp. 1056-1062, 1995.

[25] F. S. Wong, J. Karttunen, C. Dumont et al., "Identification of an MHC class I-restricted autoantigen in type 1 diabetes by screening an organ-specific cDNA library," Nature Medicine, vol. 5, no. 9, pp. 1026-1031, 1999.

[26] B. Krishnamurthy, N. L. Dudek, M. D. McKenzie et al., "Responses against islet antigens in NOD mice are prevented by tolerance to proinsulin but not IGRP," Journal of Clinical Investigation, vol. 116, no. 12, pp. 3258-3265, 2006.

[27] B. Krishnamurthy, L. Mariana, S. A. Gellert et al., "Autoimmunity to both proinsulin and IGRP is required for diabetes in nonobese diabetic 8.3 TCR transgenic mice," Journal of Immunology, vol. 180, no. 7, pp. 4458-4464, 2008.

[28] A. Amranl, J. Verdaguer, P. Serra, S. Tafuro, R. Tan, and P. Santamaria, "Progression of autoimmune diabetes driven by avidity maturation of a T- cell population," Nature, vol. 406, no. 6797, pp. 739-742, 2000.
[29] S. M. Lieberman, T. Takaki, B. Han, P. Santamaria, D. V. Serreze, and T. P. DiLorenzo, "Individual nonobese diabetic mice exhibit unique patterns of CD8+ T cell reactivity to three islet antigens, including the newly identified widely expressed dystrophia myotonica kinase," Journal of Immunology, vol. 173, no. 11, pp. 6727-6734, 2004.

[30] A. Kubosaki, S. Gross, J. Miura et al., "Targeted disruption of the IA- $2 \beta$ gene causes glucose intolerance and impairs insulin secretion but does not prevent the development of diabetes in NOD mice," Diabetes, vol. 53, no. 7, pp. 1684-1691, 2004.

[31] E. Jaeckel, L. Klein, N. Martin-Orozco, and H. Von Boehmer, "Normal incidence of diabetes in NOD mice tolerant to glutamic acid decarboxylase," Journal of Experimental Medicine, vol. 197, no. 12, pp. 1635-1644, 2003.

[32] J. Ludvigsson, M. Faresjö, M. Hjorth et al., "GAD treatment and insulin secretion in recent-onset type 1 diabetes," The New England Journal of Medicine, vol. 359, no. 18, pp. 19091920, 2008

[33] J. Chandra, B. Zhivotovsky, S. Zaitsev, L. Juntti-Berggren, P. O. Berggren, and S. Orrenius, "Role of apoptosis in pancreatic $\beta$-cell death in diabetes," Diabetes, vol. 50, supplement 1 , pp. S44-S47, 2001.

[34] A. Skowera, R. J. Ellis, R. Varela-Calviño et al., "CTLs are targeted to kill $\beta$ cells in patients with type 1 diabetes through recognition of a glucose-regulated preproinsulin epitope," Journal of Clinical Investigation, vol. 118, no. 10, pp. 33903402, 2008.

[35] M. A. Atkinson, N. K. Maclaren, and R. Luchetta, "Insulitis and diabetes in NOD mice reduced by prophylactic insulin therapy," Diabetes, vol. 39, no. 8, pp. 933-937, 1990.

[36] P. Gladstone and G. T. Nepom, "The prevention of IDDM: injecting insulin into the cytokine network," Diabetes, vol. 44, no. 7, pp. 859-862, 1995.

[37] N. Schloot and G. S. Eisenbarth, "Isohormonal therapy of endocrine autoimmunity," Immunology Today, vol. 16, no. 6, pp. 289-294, 1995.

[38] S. C. Shah, J. I. Malone, and N. E. Simpson, "A randomized trial of intensive insulin therapy in newly diagnosed insulindependent diabetes mellitus," The New England Journal of Medicine, vol. 320, no. 9, pp. 550-554, 1989.

[39] R. J. Keller, G. S. Eisenbarth, and R. A. Jackson, "Insulin prophylaxis in individuals at high risk of type I diabetes," The Lancet, vol. 341, no. 8850, pp. 927-928, 1993.

[40] M. Füchtenbusch, W. Rabl, B. Grassl, W. Bachmann, E. Standl, and A. G. Ziegler, "Delay of Type I diabetes in high risk, first degree relatives by parenteral antigen administration: the Schwabing insulin Prophylaxis Pilot Trial," Diabetologia, vol. 41, no. 5, pp. 536-541, 1998.

[41] Diabetes Prevention Trial-Type 1 Diabetes Study G, "Effects of insulin in relatives of patients with type 1 diabetes mellitus," The New England Journal of Medicine, vol. 346, pp. 1685-1691, 2002.

[42] J. C. Carel, P. Landais, P. Bougnères, C. Rodriguez-Villar, R. Casamitjana, and I. Conget, "Therapy to prevent type 1 diabetes mellitus," The New England Journal of Medicine, vol. 347, no. 14, pp. 1115-1116, 2002.

[43] J. C. Guéry, F. Galbiati, S. Smiroldo, and L. Adorini, "Selective development of T helper (Th)2 cells induced by continuous administration of low dose soluble proteins to normal and $\beta 2$-microglobulin-deficient BALB/c mice," Journal of Experimental Medicine, vol. 183, no. 2, pp. 485-497, 1996.

[44] A. Volund, J. Brange, K. Drejer et al., "In vitro and in vivo potency of insulin analogues designed for clinical use," Diabetic Medicine, vol. 8, no. 9, pp. 839-847, 1991. 
[45] D. G. Karounos, J. S. Bryson, and D. A. Cohen, "Metabolically inactive insulin analog prevents type I diabetes in prediabetic NOD mice," Journal of Clinical Investigation, vol. 100, no. 6 , pp. 1344-1348, 1997.

[46] L. Chaillous, H. Lefevre, C. Thivolet et al., "Oral insulin administration and residual beta-cell function in recentonset type 1 diabetes: a multicentre randomised controlled trial. Diabete Insuline Orale group," The Lancet, vol. 356, pp. 545-549, 2000.

[47] P. Pozzilli, D. Pitocco, N. Visalli et al., "No effect of oral insulin on residual beta-cell function in recent-onset Type I diabetes (the IMDIAB VII)," Diabetologia, vol. 43, no. 8, pp. 1000-1004, 2000.

[48] B. Ergun-Longmire, J. Marker, A. Zeidler et al., "Oral insulin therapy to prevent progression of immune-mediated (Type 1) diabetes," Annals of the New York Academy of Sciences, vol. 1029, pp. 260-277, 2004.

[49] J. S. Skyler, "Effects of oral insulin in relatives of patients with type 1 diabetes: the diabetes prevention trial-type 1," Diabetes Care, vol. 28, no. 5, pp. 1068-1076, 2005.

[50] L. C. Harrison, M. C. Honeyman, C. E. Steele et al., "Pancreatic $\beta$-cell function and immune responses to insulin after administration of intranasal insulin to humans at risk for type 1 diabetes," Diabetes Care, vol. 27, no. 10, pp. 2348$2355,2004$.

[51] K. Näntö-Salonen, A. Kupila, S. Simell et al., "Nasal insulin to prevent type 1 diabetes in children with HLA genotypes and autoantibodies conferring increased risk of disease: a doubleblind, randomised controlled trial," The Lancet, vol. 372, no. 9651, pp. 1746-1755, 2008.

[52] S. Fourlanos, C. Perry, S. A. Gellert et al., "Evidence that nasal insulin induces immune tolerance to insulin in adults with autoimmune diabetes," Diabetes, vol. 60, no. 4, pp. 1237 1245, 2011.

[53] A. Toma, S. Haddouk, J. P. Briand et al., "Recognition of a subregion of human proinsulin by class I-restricted T cells in type 1 diabetic patients," Proceedings of the National Academy of Sciences of the United States of America, vol. 102, no. 30, pp. 10581-10586, 2005.

[54] A. Toma, T. Laika, S. Haddouk et al., "Recognition of human proinsulin leader sequence by class I-restricted Tcells in HLA-A $* 0201$ transgenic mice and in human type 1 diabetes," Diabetes, vol. 58, no. 2, pp. 394-402, 2009.

[55] B. Keymeulen, E. Vandemeulebroucke, A. G. Ziegler et al., "Insulin needs after CD3-antibody therapy in new-onset type 1 diabetes," The New England Journal of Medicine, vol. 352, no. 25, pp. 2598-2608, 2005.

[56] M. Chéramy, C. Skoglund, I. Johansson, J. Ludvigsson, C. S. Hampe, and R. Casas, "GAD-alum treatment in patients with type 1 diabetes and the subsequent effect on GADA IgG subclass distribution, GAD enzyme activity and humoral response," Clinical Immunology, vol. 137, pp. 31-40, 2010.

[57] K. Koczwara, E. Bonifacio, and A. G. Ziegler, "Transmission of maternal islet antibodies and risk of autoimmune diabetes in offspring of mothers with type 1 diabetes," Diabetes, vol. 53, no. 1, pp. 1-4, 2004.

[58] S. Casares, C. A. Bona, and T. D. Brumeanu, "Enzymatically mediated engineering of multivalent MHC class II-peptide chimeras," Protein Engineering, vol. 14, no. 3, pp. 195-200, 2001.

[59] N. R. Martinez, P. Augstein, A. K. Moustakas et al., "Disabling an integral CTL epitope allows suppression of autoimmune diabetes by intranasal proinsulin peptide," Journal of Clinical Investigation, vol. 111, no. 9, pp. 1365-1371, 2003.
[60] A. Pugliese, "Peptide-based treatment for autoimmune diseases: learning how to handle a double-edged sword," Journal of Clinical Investigation, vol. 111, no. 9, pp. 1280-1282, 2003.

[61] R. Mallone, S. A. Kochik, E. M. Laughlin et al., "Differential recognition and activation thresholds in human autoreactive GAD-specific T-cells," Diabetes, vol. 53, no. 4, pp. 971-977, 2004.

[62] R. Mallone, S. A. Kochik, H. Reijonen et al., "Functional avidity directs T-cell fate in autoreactive CD4+ T cells," Blood, vol. 106, no. 8, pp. 2798-2805, 2005.

[63] B. Bielekova, B. Goodwin, N. Richert et al., "Encephalitogenic potential of the myelin basic protein peptide (amino acids 83-99) in multiple sclerosis: results of a phase II clinical trial with an altered peptide ligand," Nature Medicine, vol. 6, no. 10, pp. 1167-1175, 2000.

[64] L. Kappos, G. Comi, H. Panitch et al., "Induction of a nonencephalitogenic type $2 \mathrm{~T}$ helper-cell autoimmune response in multiple sclerosis after administration of an altered peptide ligand in a placebo-controlled, randomized phase II trial," Nature Medicine, vol. 6, no. 10, pp. 1176-1182, 2000.

[65] C. P. Genain and S. S. Zamvil, "Specific immunotherapy: one size does not fit all," Nature Medicine, vol. 6, no. 10, pp. 1098 $1100,2000$.

[66] T. Orban, K. Farkas, H. Jalahej et al., "Autoantigen-specific regulatory $\mathrm{T}$ cells induced in patients with type 1 diabetes mellitus by insulin B-chain immunotherapy," Journal of Autoimmunity, vol. 34, no. 4, pp. 408-415, 2010.

[67] S. L. Thrower, L. James, W. Hall et al., "Proinsulin peptide immunotherapy in type 1 diabetes: report of a first-in-man Phase I safety study," Clinical and Experimental Immunology, vol. 155, no. 2, pp. 156-165, 2009.

[68] S. Arif, T. I. Tree, T. P. Astill et al., "Autoreactive T cell responses show proinflammatory polarization in diabetes but a regulatory phenotype in health," Journal of Clinical Investigation, vol. 113, no. 3, pp. 451-463, 2004.

[69] I. Raz, D. Elias, A. Avron, M. Tamir, M. Metzger, and I. R. Cohen, " $\beta$-cell function in new-onset type 1 diabetes and immunomodulation with a heat-shock protein peptide (DiaPep277): a randomised, double-blind, phase II trial," The Lancet, vol. 358, no. 9295, pp. 1749-1753, 2001.

[70] I. Raz, A. Avron, M. Tamir et al., "Treatment of new-onset type 1 diabetes with peptide DiaPep277ß is safe and associated with preserved beta-cell function: extension of a randomized, double-blind, phase II trial," Diabetes/Metabolism Research and Reviews, vol. 23, no. 4, pp. 292-298, 2007.

[71] A. Zanin-Zhorov, G. Nussbaum, S. Franitza, I. R. Cohen, and O. Lider, "T cells respond to heat shock protein 60 via TLR2: activation of adhesion and inhibition of chemokine receptors," The FASEB Journal, vol. 17, no. 11, pp. 1567-1569, 2003.

[72] J. Sloan-Lancaster and P. M. Allen, "Altered peptide ligandinduced partial $\mathrm{T}$ cell activation: molecular mechanisms and role in T cell biology," Annual Review of Immunology, vol. 14, pp. 1-27, 1996.

[73] D. Daniel and D. R. Wegmann, "Protection of nonobese diabetic mice from diabetes by intranasal or subcutaneous administration of insulin peptide B-(9-23)," Proceedings of the National Academy of Sciences of the United States of America, vol. 93, no. 2, pp. 956-960, 1996.

[74] D. G. Alleva, P. D. Crowe, L. Jin et al., "A diseaseassociated cellular immune response in type 1 diabetics to an immunodominant epitope of insulin," Journal of Clinical Investigation, vol. 107, no. 2, pp. 173-180, 2001. 
[75] D. G. Alleva, A. Gaur, L. Jin et al., "Immunological characterization and therapeutic activity of an altered-peptide ligand, NBI-6024, based on the immunodominant type 1 diabetes autoantigen insulin B-chain (9-23) peptide," Diabetes, vol. 51, no. 7, pp. 2126-2134, 2002.

[76] D. G. Alleva, R. A. Maki, A. L. Putnam et al., "Immunomodulation in type 1 diabetes by NBI-6024, an altered peptide ligand of the insulin B epitope," Scandinavian Journal of Immunology, vol. 63, no. 1, pp. 59-69, 2006.

[77] M. Walter, A. Philotheou, F. Bonnici, A. G. Ziegler, and R. Jimenez, "No effect of the altered peptide ligand NBI-6024 on $\beta$-cell residual function and insulin needs in new-onset type 1 diabetes," Diabetes Care, vol. 32, no. 11, pp. 2036-2040, 2009.

[78] D. Hawiger, K. Inaba, Y. Dorsett et al., "Dendritic cells induce peripheral $\mathrm{T}$ cell unresponsiveness under steady state conditions in vivo," Journal of Experimental Medicine, vol. 194, no. 6, pp. 769-779, 2001.

[79] L. Bonifaz, D. Bonnyay, K. Mahnke, M. Rivera, M. C. Nussenzweig, and R. M. Steinman, "Efficient targeting of protein antigen to the dendritic cell receptor DEC-205 in the steady state leads to antigen presentation on major histocompatibility complex class I products and peripheral CD8+ T cell tolerance," Journal of Experimental Medicine, vol. 196, no. 12, pp. 1627-1638, 2002.

[80] L. C. Bonifaz, D. P. Bonnyay, A. Charalambous et al., "In vivo targeting of antigens to maturing dendritic cells via the DEC-205 receptor improves T cell vaccination," Journal of Experimental Medicine, vol. 199, no. 6, pp. 815-824, 2004.

[81] D. Dudziak, A. O. Kamphorst, G. F. Heidkamp et al., "Differential antigen processing by dendritic cell subsets in vivo," Science, vol. 315, no. 5808, pp. 107-111, 2007.

[82] A. Mukhopadhaya, T. Hanafusa, I. Jarchum et al., "Selective delivery of $\beta$ cell antigen to dendritic cells in vivo leads to deletion and tolerance of autoreactive CD8+ T cells in NOD mice," Proceedings of the National Academy of Sciences of the United States of America, vol. 105, no. 17, pp. 6374-6379, 2008.

[83] G. Mukherjee and T. P. Dilorenzo, "The immunotherapeutic potential of dendritic cells in type 1 diabetes," Clinical and Experimental Immunology, vol. 161, no. 2, pp. 197-207, 2010.

[84] S. D. Miller, R. P. Wetzig, and H. N. Claman, "The induction of cell-mediated immunity and tolerance with protein antigens coupled to syngeneic lymphoid cells," Journal of Experimental Medicine, vol. 149, no. 3, pp. 758-773, 1979.

[85] S. D. Miller, D. M. Turley, and J. R. Podojil, "Antigenspecific tolerance strategies for the prevention and treatment of autoimmune disease," Nature Reviews Immunology, vol. 7, no. 9, pp. 665-677, 2007.

[86] X. Luo, K. C. Herold, and S. D. Miller, "Immunotherapy of type 1 diabetes: where are we and where should we be going?" Immunity, vol. 32, no. 4, pp. 488-499, 2010.

[87] M. K. Kennedy, L. J. Tan, M. C. Dal Canto et al., "Inhibition of murine relapsing experimental autoimmune encephalomyelitis by immune tolerance to proteolipid protein and its encephalitogenic peptides," Journal of Immunology, vol. 144, no. 3, pp. 909-915, 1990.

[88] B. T. Fife, I. Guleria, M. G. Bupp et al., "Insulin-induced remission in new-onset NOD mice is maintained by the PD1-PD-L1 pathway," Journal of Experimental Medicine, vol. 203, no. 12, pp. 2737-2747, 2006.

[89] K. Inaba, S. Turley, F. Yamaide et al., "Efficient presentation of phagocytosed cellular fragments on the major histocompatibility complex class II products of dendritic cells," Journal of Experimental Medicine, vol. 188, no. 11, pp. 2163-2173, 1998.
[90] J. J. Donnelly, B. Wahren, and M. A. Liu, "DNA vaccines: progress and challenges," Journal of Immunology, vol. 175, no. 2, pp. 633-639, 2005.

[91] P. Blancou, R. Mallone, E. Martinuzzi et al., "Immunization of HLA class I transgenic mice identifies autoantigenic epitopes eliciting dominant responses in type 1 diabetes patients," Journal of Immunology, vol. 178, no. 11, pp. 74587466, 2007.

[92] E. Martinuzzi, F. A. Lemonnier, C. Boitard, and R. Mallone, "Measurement of CD8+ T cell responses in human type 1 diabetes," Annals of the New York Academy of Sciences, vol. 1150, pp. 61-67, 2008.

[93] J. A. Bluestone, A. W. Thomson, E. M. Shevach, and H. L. Weiner, "What does the future hold for cell-based tolerogenic therapy?" Nature Reviews Immunology, vol. 7, no. 8, pp. 650654, 2007.

[94] Q. Tang, K. J. Henriksen, M. Bi et al., "In vitro-expanded antigen-specific regulatory $\mathrm{T}$ cells suppress autoimmune diabetes," Journal of Experimental Medicine, vol. 199, no. 11, pp. 1455-1465, 2004.

[95] K. V. Tarbell, S. Yamazaki, K. Olson, P. Toy, and R. M. Steinman, "CD25+ CD4+ T cells, expanded with dendritic cells presenting a single autoantigenic peptide, suppress autoimmune diabetes," Journal of Experimental Medicine, vol. 199, no. 11, pp. 1467-1477, 2004.

[96] M. Battaglia, A. Stabilini, B. Migliavacca, J. Horejs-Hoeck, T. Kaupper, and M. G. Roncarolo, "Rapamycin promotes expansion of functional CD4+CD25+FOXP3+ regulatory $\mathrm{T}$ cells of both healthy subjects and type 1 diabetic patients," Journal of Immunology, vol. 177, no. 12, pp. 8338-8347, 2006.

[97] A. L. Putnam, T. M. Brusko, M. R. Lee et al., "Expansion of human regulatory T-cells from patients with type 1 diabetes," Diabetes, vol. 58, no. 3, pp. 652-662, 2009.

[98] S. A. Long, M. R. Walker, M. Rieck et al., "Functional isletspecific Treg can be generated from CD4+CD25 T cells of healthy and type 1 diabetic subjects," European Journal of Immunology, vol. 39, no. 2, pp. 612-620, 2009.

[99] J. A. Dromey, B. H. Lee, H. Yu et al., "Generation and expansion of regulatory human CD4(+) T-cell clones specific for pancreatic islet autoantigens," Journal of Autoimmunity, vol. 36, pp. 47-55, 2010.

[100] X. Zhou, S. L. Bailey-Bucktrout, L. T. Jeker et al., "Instability of the transcription factor Foxp3 leads to the generation of pathogenic memory T cells in vivo," Nature Immunology, vol. 10, no. 9, pp. 1000-1007, 2009.

[101] M. V. Dhodapkar and R. M. Steinman, "Antigen-bearing immature dendritic cells induce peptide-specific CD8(+) regulatory T cells in vivo in humans," Blood, vol. 100, no. 1, pp. 174-177, 2002.

[102] H. Hackstein, A. E. Morelli, and A. W. Thomson, "Designer dendritic cells for tolerance induction: guided not misguided missiles," Trends in Immunology, vol. 22, no. 8, pp. 437-442, 2001.

[103] J. Machen, JO. Harnaha, R. Lakomy, A. Styche, M. Trucco, and N. Giannoukakis, "Antisense oligonucleotides downregulating costimulation confer diabetes-preventive properties to nonobese diabetic mouse dendritic cells," Journal of Immunology, vol. 173, no. 7, pp. 4331-4341, 2004.

[104] R. J. Creusot, S. S. Yaghoubi, P. Chang et al., "Lymphoid tissue-specific homing of bone marrow-derived dendritic cells," Blood, vol. 113, no. 26, pp. 6638-6647, 2009.

[105] S. Kusmartsev, Y. Nefedova, D. Yoder, and D. I. Gabrilovich, "Antigen-specific inhibition of CD8 $+\mathrm{T}$ cell response by immature myeloid cells in cancer is mediated by reactive 
oxygen species," Journal of Immunology, vol. 172, no. 2, pp. 989-999, 2004.

[106] A. H. Zea, P. C. Rodriguez, M. B. Atkins et al., "Arginaseproducing myeloid suppressor cells in renal cell carcinoma patients: a mechanism of tumor evasion," Cancer Research, vol. 65, no. 8, pp. 3044-3048, 2005.

[107] BO. Huang, P. Y. Pan, Q. Li et al., "Gr-1CD115 immature myeloid suppressor cells mediate the development of tumorinduced $\mathrm{T}$ regulatory cells and T-cell anergy in tumorbearing host," Cancer Research, vol. 66, no. 2, pp. 1123-1131, 2006.

[108] M. R. Garcia, L. Ledgerwood, Y. Yang et al., "Monocytic suppressive cells mediate cardiovascular transplantation tolerance in mice," Journal of Clinical Investigation, vol. 120, no. 7, pp. 2486-2496, 2010.

[109] B. Yin, G. Ma, C.-Y. Yen et al., "Myeloid-derived suppressor cells prevent type 1 diabetes in murine models," Journal of Immunology, vol. 185, no. 10, pp. 5828-5834, 2010.

[110] K. C. Herold, B. Brooks-Worrell, J. Palmer et al., "Validity and reproducibility of measurement of islet autoreactivity by T-cell assays in subjects with early type 1 diabetes," Diabetes, vol. 58, no. 11, pp. 2588-2595, 2009.

[111] S. I. Mannering, F. S. Wong, I. Durinovic-Belló et al., "Current approaches to measuring human islet-antigen specific $\mathrm{T}$ cell function in type 1 diabetes," Clinical and Experimental Immunology, vol. 162, no. 2, pp. 197-209, 2010.

[112] R. Mallone, S. I. Mannering, B. M. Brooks-Worrell et al., "Isolation and preservation of peripheral blood mononuclear cells for analysis of islet antigen-reactive $\mathrm{T}$ cell responses: position statement of the T-Cell Workshop Committee of the Immunology of Diabetes Society," Clinical and Experimental Immunology, vol. 163, no. 1, pp. 33-49, 2011.

[113] J. L. Gaglia, A. R. Guimaraes, M. Harisinghani et al., "Noninvasive imaging of pancreatic islet inflammation in type 1A diabetes patients," Journal of Clinical Investigation, vol. 121, no. 1, pp. 442-445, 2011.

[114] M. D. Pescovitz, C. J. Greenbaum, H. Krause-Steinrauf et al., "Rituximab, B-lymphocyte depletion, and preservation of beta-cell function," The New England Journal of Medicine, vol. 361, no. 22, pp. 2143-2152, 2009.

[115] D. Bresson, L. Togher, E. Rodrigo et al., "Anti-CD3 and nasal proinsulin combination therapy enhances remission from recentonset autoimmune diabetes by inducing Tregs," Journal of Clinical Investigation, vol. 116, no. 5, pp. 1371-1381, 2006.

[116] D. Bresson and M. von Herrath, "Moving towards efficient therapies in type 1 diabetes: to combine or not to combine?" Autoimmunity Reviews, vol. 6, no. 5, pp. 315-322, 2007.

[117] J. B. Matthews, T. P. Staeva, P. L. Bernstein, M. Peakman, and M. Von Herrath, "Developing combination immunotherapies for type 1 diabetes: recommendations from the ITNJDRF Type 1 Diabetes Combination Therapy Assessment Group," Clinical and Experimental Immunology, vol. 160, no. 2, pp. 176-184, 2010.

[118] A. M. J. Shapiro, J. R. T. Lakey, E. A. Ryan et al., "Islet transplantation in seven patients with type 1 diabetes mellitus using a glucocorticoid-free immunosuppressive regimen," The New England Journal of Medicine, vol. 343, no. 4, pp. 230 $238,2000$.

[119] A. M. J. Shapiro, C. Ricordi, B. J. Hering et al., "International trial of the Edmonton protocol for islet transplantation," The New England Journal of Medicine, vol. 355, no. 13, pp. 13181330, 2006.

[120] P. Collombat, X. Xu, P. Ravassard et al., "The ectopic expression of Pax 4 in the mouse pancreas converts progenitor cells into $\alpha$ and subsequently $\beta$ cells," Cell, vol. 138, no. 3, pp. 449-462, 2009.

[121] K. I. Rother, L. M. Spain, R. A. Wesley et al., "Effects of exenatide alone and in combination with daclizumab on $\beta$ cell function in long-standing type 1 diabetes," Diabetes Care, vol. 32, no. 12, pp. 2251-2257, 2009.

[122] M. Larché, "Update on the current status of peptide immunotherapy," Journal of Allergy and Clinical Immunology, vol. 119, no. 4, pp. 906-909, 2007.

[123] P. Achenbach, J. Barker, and E. Bonifacio, "Modulating the natural history of type 1 diabetes in children at high genetic risk by mucosal insulin immunization," Current Diabetes Reports, vol. 8, no. 2, pp. 87-93, 2008. 


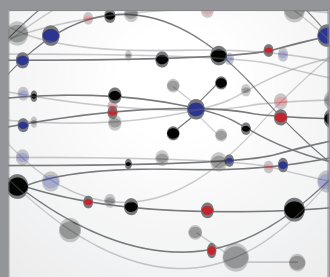

The Scientific World Journal
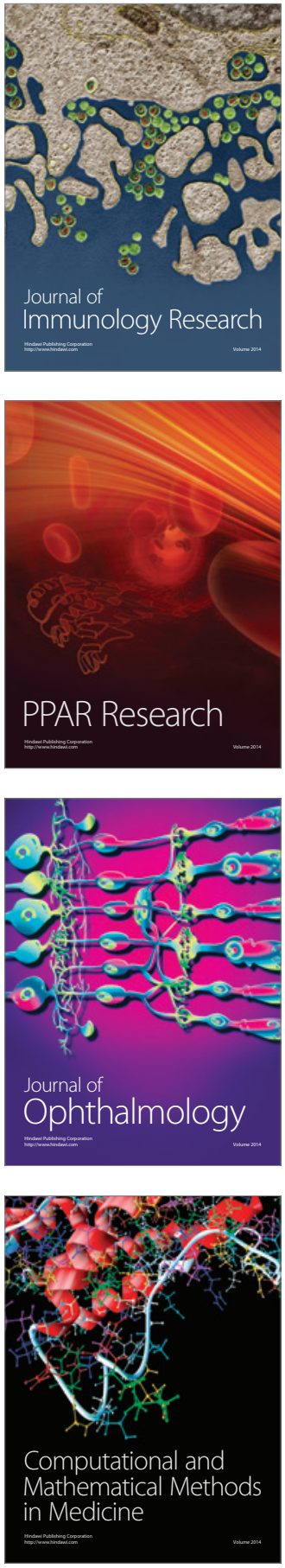

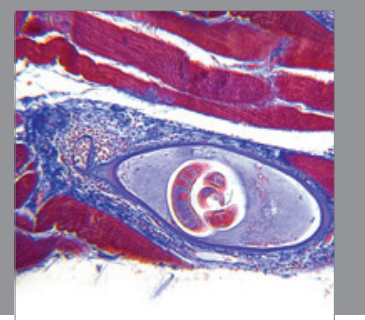

Gastroenterology

Research and Practice
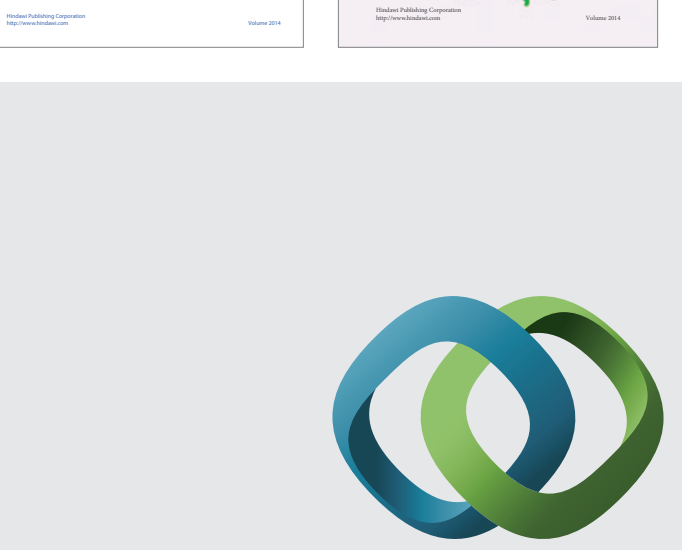

\section{Hindawi}

Submit your manuscripts at

http://www.hindawi.com
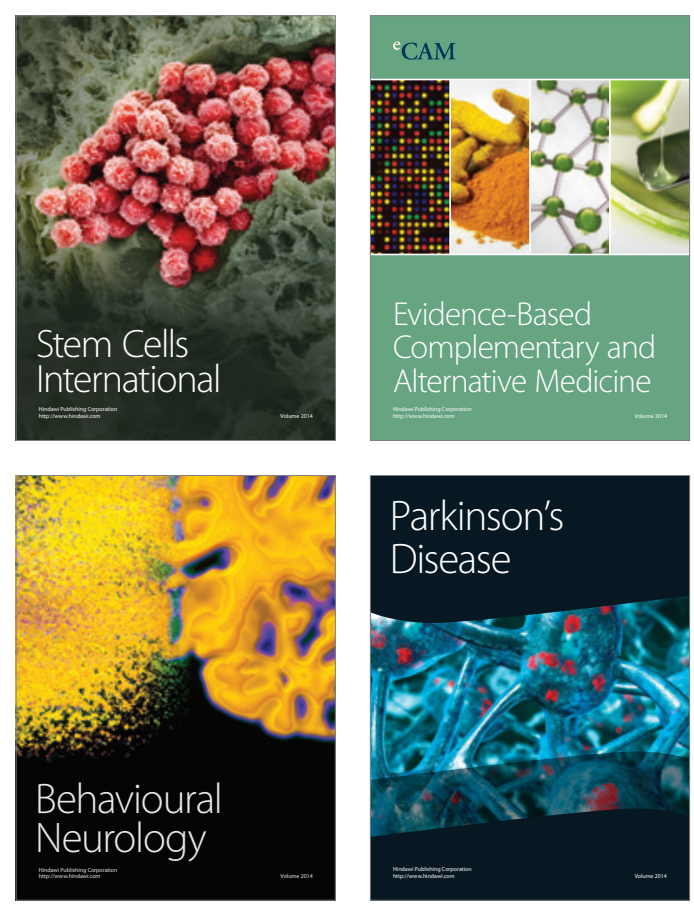

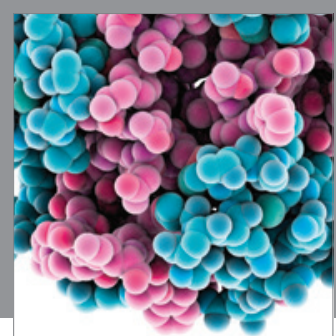

Journal of
Diabetes Research

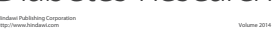

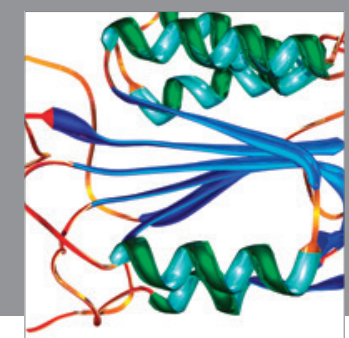

Disease Markers
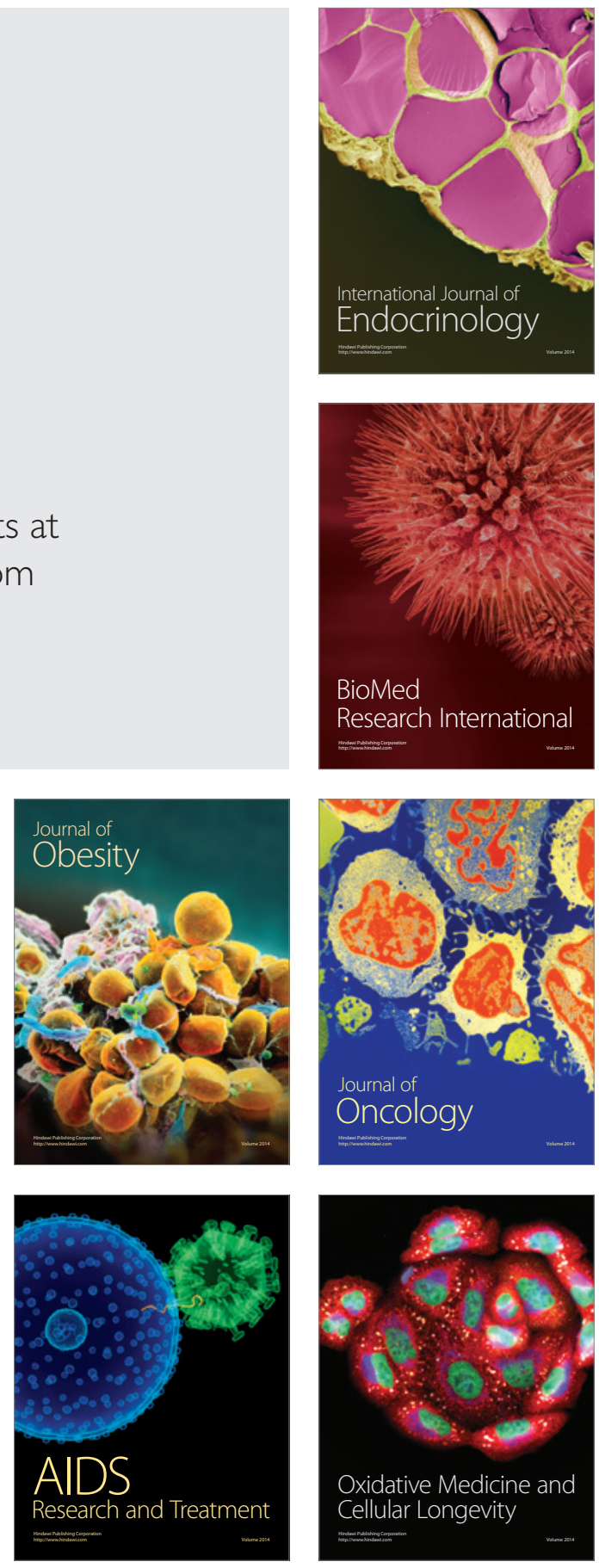